\title{
The Role of Satellite-Based Remote Sensing in Improving Simulated Streamflow: A Review
}

\author{
Dejuan Jiang $1, *\left(\mathbb{D}\right.$ and Kun Wang ${ }^{2}$ \\ 1 Key Laboratory of Coastal Environmental Processes and Ecological Remediation, Yantai Institute of Coastal \\ Zone Research, Chinese Academy of Sciences, Yantai 264003, Shandong, China \\ 2 State Key Laboratory of Remote Sensing Science, Institute of Remote Sensing and Digital Earth, Chinese \\ Academy of Sciences, Beijing 100101, China \\ * Correspondence: djjiang@yic.ac.cn
}

Received: 1 June 2019; Accepted: 1 August 2019; Published: 4 August 2019

\begin{abstract}
A hydrological model is a useful tool to study the effects of human activities and climate change on hydrology. Accordingly, the performance of hydrological modeling is vitally significant for hydrologic predictions. In watersheds with intense human activities, there are difficulties and uncertainties in model calibration and simulation. Alternative approaches, such as machine learning techniques and coupled models, can be used for streamflow predictions. However, these models also suffer from their respective limitations, especially when data are unavailable. Satellite-based remote sensing may provide a valuable contribution for hydrological predictions due to its wide coverage and increasing tempo-spatial resolutions. In this review, we provide an overview of the role of satellite-based remote sensing in streamflow simulation. First, difficulties in hydrological modeling over highly regulated basins are further discussed. Next, the performance of satellite-based remote sensing (e.g., remotely sensed data for precipitation, evapotranspiration, soil moisture, snow properties, terrestrial water storage change, land surface temperature, river width, etc.) in improving simulated streamflow is summarized. Then, the application of data assimilation for merging satellite-based remote sensing with a hydrological model is explored. Finally, a framework, using remotely sensed observations to improve streamflow predictions in highly regulated basins, is proposed for future studies. This review can be helpful to understand the effect of applying satellite-based remote sensing on hydrological modeling.
\end{abstract}

Keywords: satellite-based remote sensing; streamflow simulation; hydrological model; data assimilation

\section{Introduction}

Rivers, as the primary links between the land and ocean, play an important role in global water and energy cycles [1]. In past decades, hydrological processes and their related biogeochemical cycles in rivers have been dramatically modified as a consequence of climate and anthropogenic changes [1-9]. Especially in coastal regions with high population density and severe water shortages, intense human activities (such as land use change, urban expansion, cascade dam construction, farmland fertilization, large-scale livestock and poultry breeding, and industrial sewage discharge) pose increasing stresses to coastal ecosystems. Consequently, problems associated with the ecology and environment are very serious in these areas, particularly in the continuum of watershed, estuary, and offshore areas, such as hydrological rhythm anomalies, river channel runoff-cutting, the decrease of freshwater flux into the sea, wetland shrinkages in estuaries, seawater intrusion, offshore seawater pollution, and the decline or disappearance of land-sea ecological connectivity [7,10-14]. In such regions, hydrological processes present high nonlinearity and complexity, which cause huge challenges for accurately describing 
hydrological behavior. However, understanding and simulating hydrological processes is crucial for reasonable water resource utilization and management in these regions.

A hydrological model is a useful tool for hydrological predictions [15-17]. Particularly distributed hydrological models, which are able to reproduce the spatial and temporal evolution of a variety of hydrological processes, have been widely used for detecting changes in the hydrological regime due to human activity or/and climate change, real-time flood forecasting, drought monitoring, and water resource management [5,18-22]. Accordingly, the performance of hydrological modeling is critically important for the accurate representation of hydrological cycles [23]. However, a number of factors, such as limited ground observations and their poor temporal and spatial representativeness, inaccurate model input forcing, imperfect model structures, and empirical model parameters, may result in a degree of uncertainty in model simulations [16,24-30]. Especially in watersheds mainly governed by human decisions, there are considerable difficulties and great uncertainties in model calibration and prediction, possibly leading to incorrect model parameterization and model estimates [25,31,32].

For this reason, data-driven models, such as machine learning (ML) techniques for empirical rainfall-runoff modeling, have been proposed as a useful complement to hydrological models in the past decade [33]. For example, Artificial neural networks (ANNs), regression trees, and support vector machines (SVM) have been shown to powerful tools for discharge predictions, particularly in catchments with complex and non-linear hydrological behaviors or limited data [33-36]. The integration of a hydrological model with recurrent neural networks can also improve the accuracy of streamflow forecasting [36]. However, these data-driven models exhibit respective limitations. For instance, although the popular ANNs models do not require information on the complex nature of hydrological processes, they suffer from overfitting or overtraining, which may result in large errors in out-of-sample predictions $[33,37,38]$. It is essential to compare different approaches and choose appropriate ML approaches for hydrological predictions.

Another issue of hydrological modeling is that traditional streamflow calibration may produce low simulation accuracy for other hydrological variables, such as soil moisture, groundwater, and evapotranspiration [25,28,39-41]. Consequently, additional variables (e.g., soil moisture, evapotranspiration, and snow water equivalents), along with streamflow observations, have been applied for better model performance. Model calibration [40,42-44] and data assimilation [32,45-49], as well as their integration [50], can be used to incorporate multivariable into hydrological models to improve hydrological modeling. Especially, data assimilation shows great potential because it can update hydrological states and model parameters concurrently [45,46,49].

Moreover, some coupled models, which do not always require calibration, have been developed during the past decade (e.g., the Hydrological Modeling and Analysis Platform (HyMap) [51] and the Weather Research and Forecasting Model Hydrological modeling extension package (WRF-Hydro) [52]. These models couple atmospheric models, land surface models, and hydrologic models to produce good discharge simulations [51,52]. However, they are more appropriate for large-scale catchments. More importantly, the lack of sufficient datasets would restrict the utility of these models.

Overall, the aforementioned approaches can help greatly to enhance hydrological predictions, but their applications suffer from different limitations, especially when data are unavailable. Fortunately, satellite-based remote sensing can provide an alternative to observations of different hydrological variables (e.g., remotely sensed precipitation, evapotranspiration, soil moisture, snow water equivalents, etc.) for hydrological modeling, which have been reported by a large number of studies (e.g., [20,31,39,40,49,53]). Winsemius (2009) [54] gave a brief overview of the remote sensing estimates of hydrologic variables and their further applications in hydrological modeling. However, the satellite information was out of date and was limited only to the terrestrial water storage (TWS) from the Gravity Recovery and Climate Experiment (GRACE), satellite-based evaporation, and rainfall estimates. Sheffield et al. (2018) [55] provided an overview about the current and potential future role of satellite remote sensing in improving water resource management. However, their review has focused on examples for Latin America Caribbean (LAC), and has emphasized water resource management rather than hydrological modeling. 
In view of this, we comprehensively summarize the role of satellite-based remote sensing in streamflow simulations. In Section 2, difficulties in hydrological modeling over highly regulated basins are further discussed. Section 3 provides an overview of the performance of satellite-based remote sensing in enhancing simulated streamflow. Section 4 introduces the application of data assimilation for merging satellite-based remote sensing with a hydrological model. Section 5 offers summaries and discussions, as well as outlooks. Particularly, future studies are recommended to determine how to apply remotely sensed observations for improving simulated streamflow in highly regulated basins.

\section{Difficulties in Hydrological Modeling over Highly Regulated Basins}

A distributed hydrological model, as a physically-based model, requires numerous ground observations as well as model parameter optimization. The scarcity or spatial mismatch of observed data will restrict the model application [28]. Moreover, human activity, particularly water consumption and cascade dam construction, further increases the difficulty in hydrological forecasting. To perform hydrological modeling in human-impacted watersheds, Wang and Jia (2016) [7] established a nature-society dualistic water cycle theory to support effective solutions for water-related issues. This theory has greatly promoted the research progress of water cycle evolution mechanisms. Based on this theory, Sang et al. (2008) [56] developed an agriculture management module and a consumptive water use module, which updated the Soil and Water Assessment Tool (SWAT) model. Their results showed that the updated model could be applied successfully to the highly regulated region (Tianjin City of China). Zhang et al. (2011) [57] developed a water quantity and quality joint mode of dam and floodgate operations based on the SWAT model, which more realistically simulated the process of water quantity and quality controlled by dams and floodgates in the Wenyu River basin of Beijing city.

The aforementioned improvement in hydrological models can help to simulate water quantity and quality in watersheds under strong human influence. Nevertheless, this work is still hampered by data scarcity or mismatches. On the one hand, the survey data for water consumption or its estimation commonly have coarser spatial and temporal resolutions, which cannot elaborate inter-annual and intra-annual variations in water consumption. Furthermore, there is difficulty in extending these data to the spatial dimension of distributed hydrological models, because the primary spatial unit of these models is the grid or sub-basin (and further hydrologic response unit). On the other hand, it is difficult to gain observed inflow and outflow data for reservoirs and dams. Moreover, there is significant randomness for the artificial regulation of reservoirs and dams. Additionally, there may be no monitoring stations for many small and medium-sized reservoirs and dams. These disadvantages can significantly affect the performance of hydrological modeling.

In addition, hydrological model calibration using streamflow observations alone would be questionable. Commonly, hydrological models have been calibrated by adjusting model parameters to make the simulated streamflow agreeing with observations (particularly at the outlet of a watershed) [58,59], but a calibrated parameter set with the satisfactory results of a simulated streamflow at a limited number of discharge locations does not warrant the performance at most locations within a watershed $[25,28,60]$. Moreover, streamflow-only calibration, except for the inaccurately observed meteorological forcing inputs (e.g., precipitation and temperature) and the imperfect model structure, may also reproduce unreliable simulation results of a second model output variable, as mentioned above [39,40,61].

In general, the aforementioned deficiencies can lead to large uncertainties in hydrological modeling, which would hinder the application of hydrological models.

\section{The Role of Satellite-Based Remote Sensing in Improving Simulated Streamflow}

\subsection{Remotely Sensed Precipitation}

Precipitation is a major component of the hydrologic cycle and is the critical input for hydrological models [62-74]. Accurate and continuous precipitation estimates are essential for reliable hydrological simulations of fluxes and states $[17,73,75]$. However, poor precipitation observations (e.g., poor continuity 
in time and space) may lead to non-linear propagated errors in streamflow simulations [66,76-79]. This, possibly, results in unsatisfactory model performance. In addition, the precision of precipitation data may significantly affect the capability of other remotely sensed data (regarding evapotranspiration, soil moisture, snow properties, terrestrial water storages changes (TWSC), etc.) for improving streamflow estimates. Hence, appropriate precipitation data are the prerequisite for guaranteeing hydrological modeling.

Traditional rain gauge measurements can provide accurate precipitation data, but uneven spatial coverage or scarce rain gauges may cause great uncertainty [64,66,78,80-82]. In contrast, a variety of satellite precipitation products, such as Tropical Rainfall Measuring Mission (TRMM) Multisatellite Precipitation Analysis (TMPA) [83], Integrated Multi-satellite Retrievals for Global Precipitation Measurement (GPM-IMERG), which is a global successor to TRMM [84], Climate Prediction Center Morphing technique (CMORPH) [85], Precipitation Estimation from Remotely Sensed Information Using Artificial Neural Networks (PERSIANN) [86], Global Satellite Mapping of Precipitation (GSMaP) [87], and Naval Research Laboratory Global Blended-Statistical Precipitation Analysis Data (NRL-Blend) [88], can offer a promising alternative source on a global scale, with increasing temporal and spatial resolutions. These products have been applied in a wide range of hydrological applications from water resource modeling to drought and flood monitoring (e.g., [68-70,73,74,76,79,89-96]) (Table 1).

In general, the capability and feasibility of satellite rainfall estimate (SRE) in driving hydrological models vary largely due to differences in topography, season, climate, basin size, selected hydrological model, and satellite product type [17,63,69,73,79,91,97-100]. SREs demonstrate a potential hydrologic ability in data-sparse, ungauged, or large-scale catchments, compared to in situ rainfall measurements (e.g., [65,72,76,91-93,97,100]). For instance, Yuan et al. (2018) [72] assessed the hydrologic utility of IMERG and TMPA 3B42 Version 7 in the Yellow Source Region with a sparse rain-gauge network. Their results indicated that, generally, both the IMERG- and 3B42V7-forced daily streamflow simulations were slightly less accurate than those driven by the gauge-based precipitation input in the calibration period, but the performance of the IMERG-based simulation in the validation period surpassed even the model run using the gauge-based precipitation data set. However, in most other areas, SREs have the difficulty to outperform or be equal to rain gauges for rainfall estimates and further hydrological applications due to their seasonal and regional systematic biases and random errors [63,74,89,91,94,100-102].

Therefore, prior to their implementation to the hydrological model, SREs require thorough validation and commonly need bias correction based on rain gauge data $[17,71,74,78,89,91,102,103]$. Falck et al. (2018) [75] concluded that the corrected radar rainfall estimates reduced the systematic error of the streamflow ensemble for most sub-basins compared with the rain gauge, and significantly improved the simulated streamflow during nine flood events. Zhang et al. (2019) [17] discovered that the adjusted TMPA 3b42V7 improved the performance of the simulated streamflow better than the original TMPA $3 \mathrm{~b} 42 \mathrm{~V} 7 \mathrm{data}$, and performed even better than rain-gauge observation in the validation period.

In addition, some studies showed that the model recalibration employing SREs could increase the performance of the streamflow simulation, comparable to the model calibrated with rain gauge data $[63,72,89,91,96,104]$, because the new parameter settings can compensate for errors in the satellite rainfall forcing [79]. For example, Yuan et al. (2018) [72] found that the input-specific model recalibration effectively improved the performance of the daily streamflow simulations using IMERG (Nash Sutcliffe Efficiency (NSE) was 0.856) and 3B42V7 (NSE = 0.840), exceeding that of the gauge-forced model run $(\mathrm{NSE}=0.807)$. However, it should be noted that the parameter values through recalibrating models with SREs may be unrealistic, thereby limiting the model's predictive capability at the sub-basin scale [79].

Overall, a number of studies evaluated the hydrologic utility of different SREs, but most studies have demonstrated the limited capability of SREs as the input forcing, compared to ground observations. Thus, in the future, remote sensing rainfall products have still a long way from replacing ground observations, which produce the most accurate hydrological simulations [102]. 
Table 1. Relevant studies using satellite-based precipitation products to drive hydrological simulations.

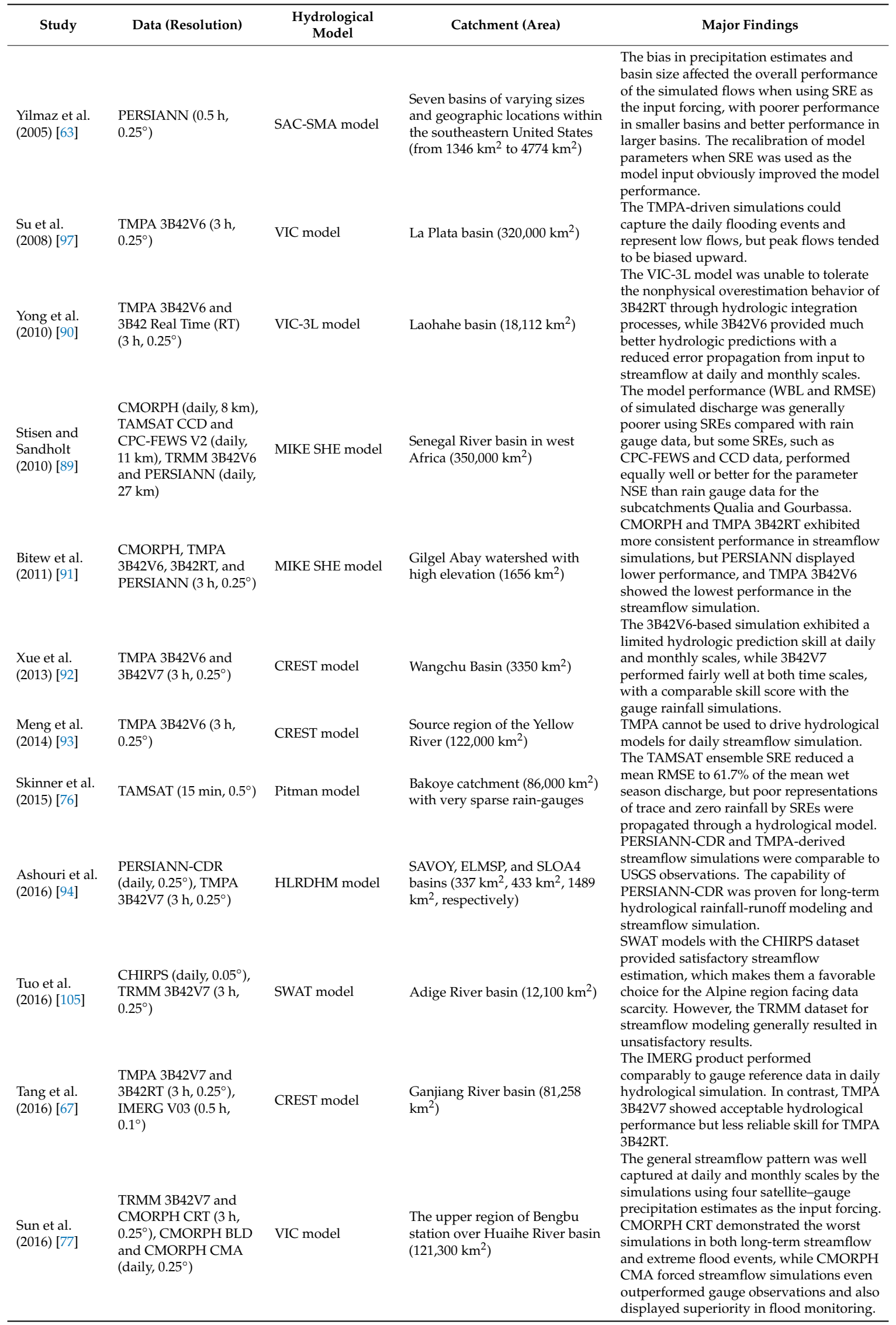


Table 1. Cont.

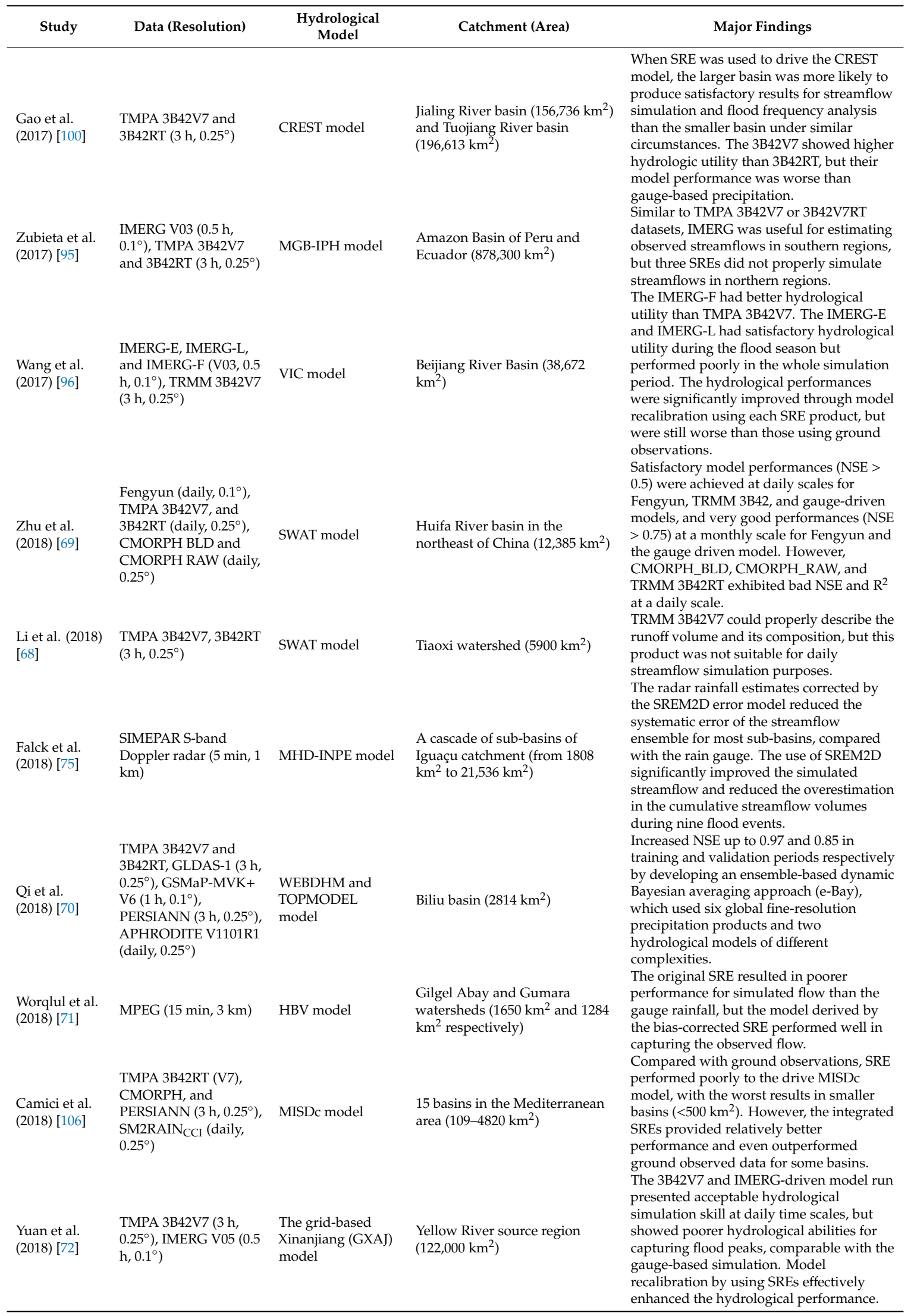


Table 1. Cont.

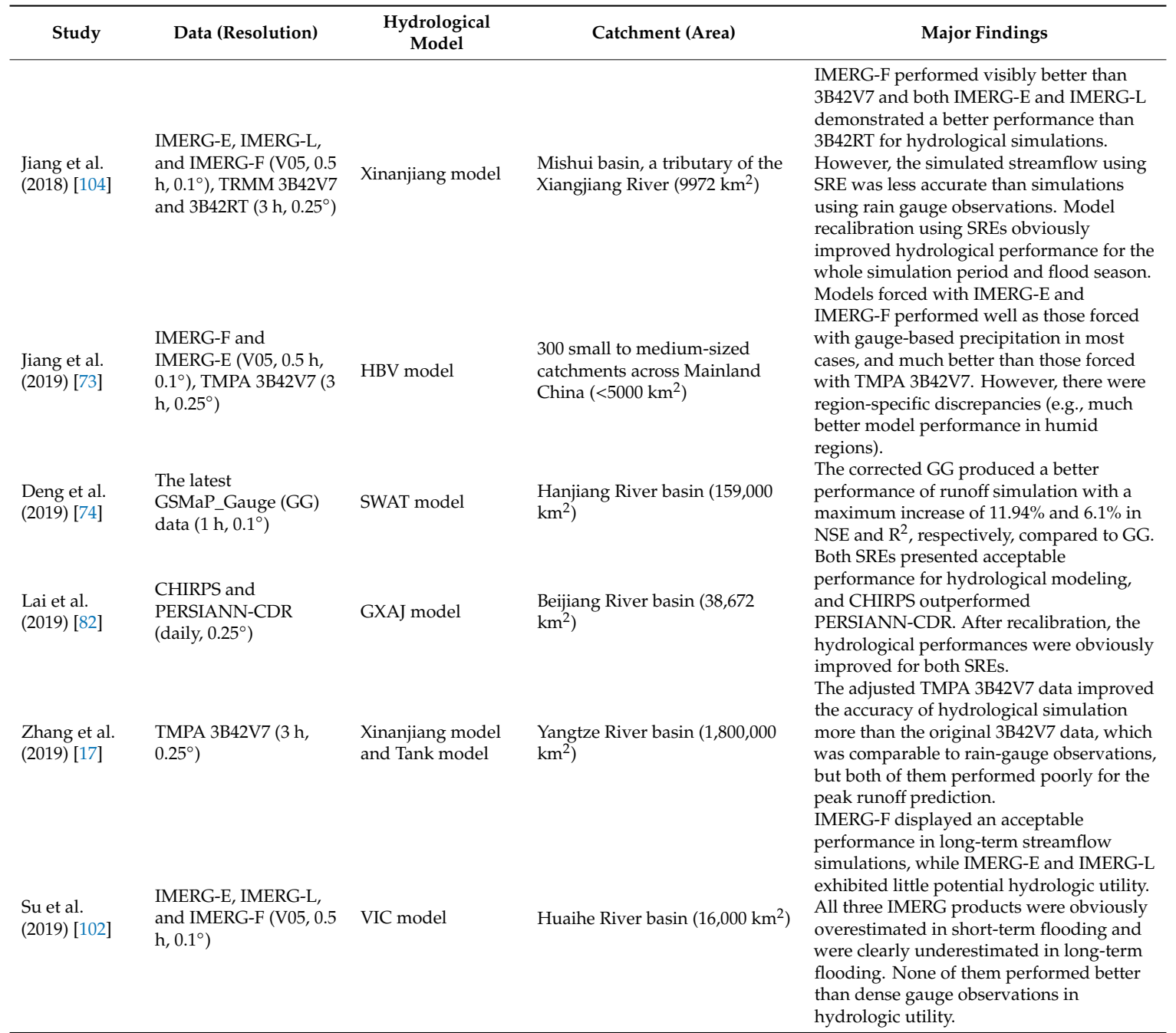

Abbreviations: SAC-SMA, Sacramento Soil Moisture Accounting model; VIC, Variable Infiltration Capacity; VIC-3L, the three-layer VIC; TAMSAT, Tropical Applications of Meteorology using SATellite data; TAMSAT CCD, the cold cloud duration using TAMSAT data; CPC-FEWS, Climate Prediction Center/Famine Early Warning System; WBL, water balance error; RMSE, root-mean-square error; CREST, Coupled Routing and Excess Storage; TAMSIM, TAMSAT Simulation; PERSIANN-CDR, PERSIANN-Climate Data Record; HLRDHM, Hydrology Laboratory Research Distributed Hydrologic Model; CHIRPS, Climate Hazards Group InfraRed Precipitation with Station data; CMORPH CRT, CMORPH bias-corrected product; CMORPH_BLD, CMORPH satellite-gauge blended product; CMORPH CMA, CMORPH satellite-gauge merged product developed at the National Meteorological Information Center (NMIC) of the China Meteorological Administration (CMA); MGB-IPH, Large Scale Basins Model of Brazilian Institute of Hydraulic Research; IMERG-E, the near-real-time "Early" run of IMERG; IMERG-L, the near-real-time "Late" run of IMERG; IMERG-F, the post-real-time "Final" run of IMERG; CMORPH_RAW, CMORPH raw satellite-only precipitation product; $\mathrm{R}^{2}$, coefficient of determination; SIMEPAR, Paraná Meteorologic System; MHD-INPE, Modelo Hidrológico Distribuído of Brazilian Institute for Space Research; SREM2D, the 2-Dimensional Satellite Rainfall Error Model; GLDAS, Global Land Data Assimilation System; GSMaP-MVK+, GSMAP moving vector with Kalman filter; APHRODITE, Asian Precipitation-Highly-Resolved Observational Data Integration Towards Evaluation of Water Resources; WEBDHM, Water and Energy Budget-based Distributed Hydrological Model; TOPMODEL, TOPography based hydrological MODEL; MPEG, Multi-sensor precipitation estimate-geostationary; HBV, Hydrologiska Byråns Vattenbalansavdelning; SM2RAIN $\mathrm{CCl}_{\text {, the derived rainfall }}$ obtained by applying SM2RAIN to the European Space Agency Climate Change Initiative Soil Moisture (ESA CCI SM) products; MISDc, Modello Idrologico Semi-Distribuito in continuo; GSMaP_Gauge, a product that adjusts the GSMaP_MVK estimate with global gauge analysis supplied by the National Oceanic and Atmospheric Administration (NOAA).

\subsection{Remotely Sensed Evapotranspiration}

Evapotranspiration (ET) is a major component of the water and energy exchanges among the atmosphere, hydrosphere, and biosphere $[107,108]$. Integrating actual $\mathrm{ET}\left(\mathrm{ET}_{\mathrm{a}}\right)$ data into hydrological 
models makes it possible to improve hydrological modeling, especially for highly regulated basins (Table 2). For example, Immerzeel et al. (2008) [25] successfully calibrated the SWAT model using the remotely sensed derived ET in the upper Bhima catchment $\left(45,678 \mathrm{~km}^{2}\right)$, where streamflow was mainly human controlled. The correlation coefficient between the monthly sub-basin simulated and measured $\mathrm{ET}_{\mathrm{a}}$ increased from 0.40 to 0.81 . Hartanto et al. (2017) [31] assimilated the satellite-based $\mathrm{ET}_{\mathrm{a}}$ into a distributed hydrological model at a controlled water system. Their results showed that the modelled cumulative discharge was improved, with the bias decreasing from $14 \%$ to $4 \%$.

In general, there are few studies on the application of satellite-based $\mathrm{ET}_{\mathrm{a}}$ data to enhance streamflow simulations, and most of them are limited to larger catchments (Table 2). On the one hand, $\mathrm{ET}_{\mathrm{a}}$ is a non-state variable in hydrological models, which cannot achieve assimilation feedback for the model and update model state variables when data assimilation methods are used to combine $\mathrm{ET}_{\mathrm{a}}$ with hydrological models [109]. Hence, the hydrological models cannot be optimized as a whole. This restricts the application of $\mathrm{ET}_{\mathrm{a}}$ observations in most hydrological models, in which, inversely, state variables (e.g., soil moisture) are used for the $\mathrm{ET}_{\mathrm{a}}$ estimate. Certainly, if the time response relationship between $\mathrm{ET}_{\mathrm{a}}$ and state variables were well established, the model optimization and more accurate hydrological estimates could be obtained [109,110]. For example, Zou et al. (2017) [108] established the time response relationship between $\mathrm{ET}_{\mathrm{a}}$ and soil moisture using a nonlinear soil water availability function based on logistic distribution, which achieved more accurate results for $\mathrm{ET}_{\mathrm{a}}$, as well as streamflow and soil moisture. However, it is noteworthy that most hydrological models show no explicit time response relationship between $\mathrm{ET}_{\mathrm{a}}$ and the state variable (e.g., soil moisture). Thus, it is hard to effectively convert $\mathrm{ET}_{\mathrm{a}}$ into a state variable for realizing the direct assimilation and achieving assimilation feedback on state variables $[108,110]$. Moreover, soil moisture conversion functions may vary in their soil wetness and leaf-area index $[108,111,112]$. In this respect, further studies are expected to be conducted to improve both $\mathrm{ET}_{\mathrm{a}}$ estimation and other model predictions, especially in the small and middle watersheds.

On the other hand, $\mathrm{ET}_{\mathrm{a}}$ is inherently difficult to be measured and predicted, but an accurate $\mathrm{ET}_{\mathrm{a}}$ is critical for its application in hydrological modeling. Many researchers have been making great efforts in $\mathrm{ET}_{\mathrm{a}}$ estimation, particularly using remote sensing methods, because of the relatively contiguous measurements for surface biophysical variables affecting ET at regional to global scales. Zhang et al. (2016) [113] summarized existing major remote sensing ET $_{\mathrm{a}}$ estimation methods, as well as their uncertainties and limitations, and provided a perspective on the future development of these methods. Improvement in satellite-based remote sensing in the future will enhance our capability to monitor global water and energy cycles [113]. Accordingly, satellite-based $\mathrm{ET}_{\mathrm{a}}$ data would make greater contributions to the improvement of hydrological predictions.

Table 2. Relevant studies on improving hydrological simulations using satellite-based $\mathrm{ET}_{\mathrm{a}}$.

\begin{tabular}{|c|c|c|c|c|c|}
\hline Study & $\begin{array}{c}\text { ET }_{\text {a }} \text { Estimation } \\
\text { Method }\end{array}$ & Data (Resolution) & $\begin{array}{l}\text { Hydrological } \\
\text { Model }\end{array}$ & Catchment (Area) & Major Findings \\
\hline $\begin{array}{l}\text { Immerzeel et al. } \\
(2008) \text { [25] }\end{array}$ & SEBAL & $\begin{array}{l}\text { MODIS ( } 250 \mathrm{~m} \text {, } \\
\text { monthly) }\end{array}$ & SWAT model & $\begin{array}{l}\text { Upper Bhima } \\
\text { catchment } \\
\left(45,678 \mathrm{~km}^{2}\right)\end{array}$ & $\begin{array}{l}\text { Significantly improved } \mathrm{ET}_{\mathrm{a}} \\
\text { estimates. Modelled discharges } \\
\text { were well within one standard } \\
\text { deviation of the observed data. } \\
\text { Obtained the probabilistically }\end{array}$ \\
\hline $\begin{array}{l}\text { Pan et al. (2008) } \\
\text { [114] }\end{array}$ & SEBS & $\begin{array}{l}\text { MODIS (5 km, } \\
\text { daily) }\end{array}$ & VIC model & $\begin{array}{l}\text { Red-Arkansas } \\
\text { River Basin } \\
\left(645,000 \mathrm{~km}^{2}\right)\end{array}$ & $\begin{array}{l}\text { optimal ET estimates, but was } \\
\text { unable to improve other model } \\
\text { predictions (e.g., soil moisture and } \\
\text { streamflow). }\end{array}$ \\
\hline $\begin{array}{l}\text { Qin et al. (2008) } \\
\text { [115] }\end{array}$ & SEBS & $\begin{array}{l}\text { MODIS (1 km, } \\
\text { monthly) }\end{array}$ & WEP-L model & $\begin{array}{l}\text { Huai River Basin } \\
\left(317,800 \mathrm{~km}^{2}\right)\end{array}$ & $\begin{array}{l}\text { Obtained more accurate ET } \\
\text { estimates, but contributed little to } \\
\text { the estimated water budget terms } \\
\text { (e.g., soil moisture and } \\
\text { streamflow) }\end{array}$ \\
\hline
\end{tabular}


Table 2. Cont.

\begin{tabular}{|c|c|c|c|c|c|}
\hline Study & $\begin{array}{c}\text { ET }_{\mathrm{a}} \text { Estimation } \\
\text { Method }\end{array}$ & Data (Resolution) & $\begin{array}{l}\text { Hydrological } \\
\text { Model }\end{array}$ & Catchment (Area) & Major Findings \\
\hline $\begin{array}{l}\text { Rientjes et al. } \\
(2013) \text { [42] }\end{array}$ & SEBS & $\begin{array}{l}\text { MODIS (1 km, } \\
\text { daily) }\end{array}$ & HBV model & $\begin{array}{l}\text { Karkheh River } \\
\text { Basin }\left(51,000 \mathrm{~km}^{2}\right)\end{array}$ & $\begin{array}{l}\text { Produced satisfying estimates for } \\
\text { both streamflow and } \mathrm{ET}_{\mathrm{a}} \text { and } \\
\text { reproduced the catchment water } \\
\text { balance through the } \\
\text { multi-variable calibration of } \\
\text { streamflow and satellite-based } \\
\mathrm{ET}_{\mathrm{a}} \text {, compared to the } \\
\text { single-variable calibration, which } \\
\text { provided poor simulation } \\
\text { performance for the second } \\
\text { variable (streamflow or } \mathrm{ET}_{\mathrm{a}} \text { ) and } \\
\text { poor reproduction of the water } \\
\text { balance. }\end{array}$ \\
\hline $\begin{array}{l}\text { Zou et al. } \\
\text { (2017) [108] }\end{array}$ & $\begin{array}{l}\text { Improved ET } \\
\text { algorithm by } \\
\text { Mu et al. } 2011 \\
\text { [116] }\end{array}$ & $\begin{array}{l}\text { MOD16A2 ET } \\
\text { data }(1 \mathrm{~km}, 8 \text {-day) }\end{array}$ & DTVGM model & $\begin{array}{l}\text { Upper Huai River } \\
\text { Basin }\left(30,630 \mathrm{~km}^{2}\right)\end{array}$ & $\begin{array}{l}\text { Improved the accuracy of } \\
\text { spatiotemporal variations of } \mathrm{ET}_{\mathrm{a}} \\
\text { and the simulation performance } \\
\text { of both soil moisture and } \\
\text { streamflow. }\end{array}$ \\
\hline $\begin{array}{l}\text { Hartanto et al. } \\
\text { (2017) [31] }\end{array}$ & $\begin{array}{l}\text { The } \\
\text { ITA-MyWater } \\
\text { algorithm }\end{array}$ & $\begin{array}{l}\text { MODIS } \\
\text { (250-500 m, 8-day) }\end{array}$ & $\begin{array}{l}\text { SIMGRO } \\
\text { model }\end{array}$ & $\begin{array}{l}\text { Rijnland area } \\
\left(1200 \mathrm{~km}^{2}\right)\end{array}$ & $\begin{array}{l}\text { Improved the discharge modeling } \\
\text { and reduced the bias of simulated } \\
\text { cumulative discharge to the } \\
\text { observed data from } 14 \% \text { to } 4 \% \text {. } \\
\text { Improved } \mathrm{ET}_{\mathrm{a}} \text { estimations when } \\
\text { maintaining the performance of } \\
\text { streamflow estimates through } \\
\text { multi-variable calibration using }\end{array}$ \\
\hline $\begin{array}{l}\text { Herman et al. } \\
\text { (2018) [117] }\end{array}$ & $\begin{array}{l}\text { SSEBop model } \\
\text { and ALEXI } \\
\text { model }\end{array}$ & $\begin{array}{l}\text { MODIS (1 km, } \\
\text { 8-day), remotely } \\
\text { sensed land surface } \\
\text { temperatures } \\
\text { (4 km, daily) }\end{array}$ & SWAT model & $\begin{array}{l}\text { Honeyoey } \\
\text { Creek-Pine Creek } \\
\text { Watershed } \\
(\text { approximately } \\
\left.1100 \mathrm{~km}^{2}\right)\end{array}$ & $\begin{array}{l}\mathrm{ET}_{\mathrm{a}} \text { and streamflow, compared } \\
\text { with the GA calibration using } \mathrm{ET}_{\mathrm{a}} \\
\text { alone, which produced better } \mathrm{ET}_{\mathrm{a}} \\
\text { simulations but lowered } \\
\text { streamflow calibrations. }\end{array}$ \\
\hline
\end{tabular}

Abbreviations: SEBAL, Surface Energy Balance Algorithm for Land; MODIS, Moderate Resolution Imaging Spectrometer; SEBS, Surface Energy Balance System; WEP-L, Water and Energy transfer Process in Large river basins; MOD16, MODIS global evapotranspiration product; DTVGM, Distributed Time-Variant Gain Model; ITA-MyWater algorithm, Integrated Thermodynamic Algorithms for MyWater project, which is an adaptation of SEBAL; SIMGRO, SIMulation of GROundwater and surface water levels; SSEBop, Simplified Surface Energy Balance; ALEXI, Atmosphere-Land Exchange Inverse; GA, Genic Algorithm.

\subsection{Remotely Sensed Soil Moisture}

Soil moisture, interacting with surface water and groundwater, affects a variety of hydrological processes [118-122]. It controls the partitioning of rainfall into infiltration and runoff, subsequently controlling water movement and baseflow generation from the soil profile and determining streamflow and flooding $[15,29,118,123,124]$. The integration of soil moisture information into hydrological models has the potential to enhance hydrological modeling predictability $[21,39,40,118,121,125-127]$ (Table 3). Although limited improvement in streamflow simulations has been produced in a small watershed, which has better in-situ observations, by coupling soil moisture data, the performance of the runoff prediction in the presence of larger errors in precipitation observations [123] and flood predictions $[45,126,128]$ showed a significant improvement. In watersheds which have no available data, data scarcity, transient rivers, man-controlled runoff, large scales, semi-arid or arid climates, soil moisture data demonstrate the importance in achieving more accurate streamflow estimates [21,39,45,118,123,129-131].

Commonly, soil moisture monitoring can be obtained from in situ and satellite observations. In situ measurements can provide accurate soil moisture information over the entire root zone for hydrological modeling, but they represent soil moisture conditions only over a small spatial scale and are unable to characterize the spatial heterogeneity and variability of soil moisture over a large scale [118,122,132,133]. Satellite-based remote sensing can provide an alternative to develop observations for soil moisture with a large range and high accuracy, which can fill in gaps with sparse ground measurements or poor 
spatial representativeness $[121,122,126,132,134]$. Among these techniques, microwave remote sensing (passive and active) has been widely applied for the retrieval of global soil moisture [135], because microwave sensors are not limited by cloud cover and nighttime conditions [122]. In contrast to active sensors, passive microwave sensors, like the Soil Moisture and Ocean Salinity (SMOS), Advanced Microwave Scanning Radiometer for EOS (AMSR-E), and the Soil Moisture Active Passive (SMAP), have a more mature algorithm for surface soil moisture inversion and a larger soil penetration depth. However, they are less sensitive to the influence of vegetation structure, surface roughness, snow cover, frozen soil, and precipitation events due to their poor spatial resolution $[15,122]$. Active microwave sensors, such as the Advanced Scatterometer (ASCAT), have higher spatial and temporal resolutions and a better accuracy because of less radiofrequency interference, but they have a lower soil penetration depth $(0.5-2 \mathrm{~cm})$ [15]. Early studies concluded that passive microwave products were more reliable over bare to sparsely vegetated regions, but their performance decreased with increasing vegetation density [136]. In contrast, active microwave products performed better over moderately vegetated regions [137]. However, neither satellite products can provide accurate soil moisture estimates over dense vegetation cover [136,138].

Some researchers investigated the influence of different satellite soil moisture products on hydrological predictions. For example, Laiolo et al. (2016) [20] concluded that assimilating the H07 (surface soil moisture product over Europe and North Africa with a spatial resolution of $25 \mathrm{~km}$ ) and H14 products (soil moisture profile index in the root region by scatterometer data assimilation with a $25 \mathrm{~km}$ resolution) derived from ASCAT observations in the Satellite Application Facility on Support to Operational Hydrology and Water Management (H-SAF) project provided the greatest benefits to the discharge model predictions. However, the assimilation of SMOS only produced a weak improvement of the model's performance due to the few data available and the data quality $(43 \mathrm{~km}$ average resolution). The H08 product, which was disaggregated and re-sampled from $\mathrm{H} 07$ at fine scale $(1 \mathrm{~km})$ for hydrological applications, did not obtain better results than H07. This suggested that the disaggregation process did not bring benefits. Patil and Ramsankaran (2018) [124] found that in the Wyara catchment of India $\left(1650 \mathrm{~km}^{2}\right)$, the SMOS observations obtained better assimilation efficiency than ASCAT observations, but the opposite result was found in for the Varada catchment of India $\left(5092 \mathrm{~km}^{2}\right)$. Generally, the impact of different satellite soil moisture products on streamflow simulations is rarely compared. More attention has been paid to assessing the accuracy of remote sensing estimates of soil moisture at regional or global scales.

In addition, it should be noted that remotely sensed soil moisture products can only provide an estimate of soil moisture in the top few centimeters $(\sim 5 \mathrm{~cm})$ of the profile [123]. Therefore, the application of these products has focused on surface runoff and storm-related flooding type events. However, the subsurface and root-zone soil moisture have a more significant effect on runoff simulation $[123,127,139]$. Several studies explored the potential of surface soil moisture estimates to update subsurface soil moisture in hydrological modeling using data assimilation techniques [21,124]. For instance, Patil and Ramsankaran (2017) [21] assimilated satellite-based soil moisture into the SWAT model in the Munneru catchment and found that perturbing the field capacity of soil can significantly improve the coupling between the surface and subsurface layers, despite producing moderate improvement in streamflow estimates. Subsequently, Patil and Ramsankaran (2018) [124] coupled the Soil Moisture Analytical Relationship (SMAR) into the SWAT model to update the sub-surface soil moisture at the Wyra river catchment and Varada catchment in India. They found that this scheme could produce a better improvement in surface flow, groundwater flow, and streamflow estimates. However, the improvement in streamflow simulations was still moderate, because updating the soil moisture alone could insufficiently remedy the errors in streamflow simulations, that originated from erroneous model forcing in subsequent days. In order to get the root zone soil moisture information, Wanders et al. (1999) [140] proposed the Exponential Filter method based on the surface observations of satellite products. Some researchers, such as Brocca et al. (2012) [139] and Massari et al. 
(2015) [29], applied this approach to estimate the soil water index of the root zone and then assimilated it into the hydrological model to improve discharge predictions.

In general, coupling remote sensed soil moisture data into hydrological models can be beneficial for hydrological predictions. However, simulation performance is affected by a variety of factors, including the selected hydrological model [15,49], catchment characteristics [15,29,141], data availability $[47,141]$, assimilation or calibration procedure $[40,46,50,120,125,142,143]$, as well as the rescaling technique of satellite products $[15,20,29,126]$. As mentioned above, data assimilation and model calibration are expected to improve hydrological modeling in different ways [50]. Koster et al. (2018) [50] compared the data assimilation and model calibration in contributions to hydrological estimation by integrating SMAP soil moisture data into a land surface model. Their results showed that 1) two approaches were distinct and largely complementary in contributions to simulations of both streamflow and soil moisture; 2) data assimilation improved streamflow timing and reduced the unbiased RMSE (ubRMSE) of soil moisture estimates, while model calibration reduced the model biases in both streamflow and soil moisture; and 3) the joint use of two approaches provided the highest soil moisture simulation accuracy. Consequently, data assimilation and model calibration demonstrate their own advantages in streamflow predictions. However, overall, data assimilation has gained more applications in incorporating remotely sensed soil moisture products into hydrological models for better model performance (Table 3).

Table 3. Relevant studies of the applied satellite-based soil moisture data for improving hydrological simulations.

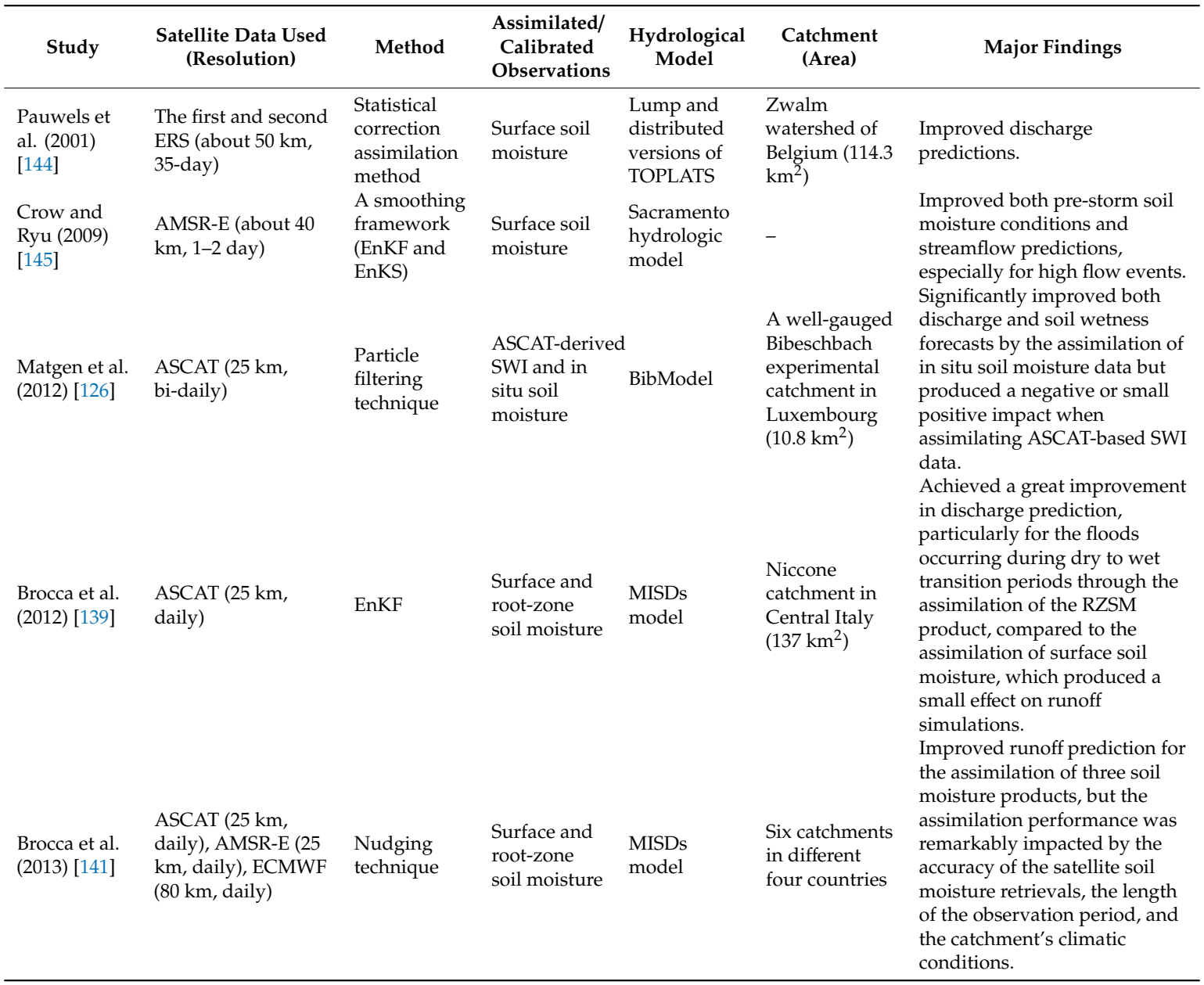


Table 3. Cont.

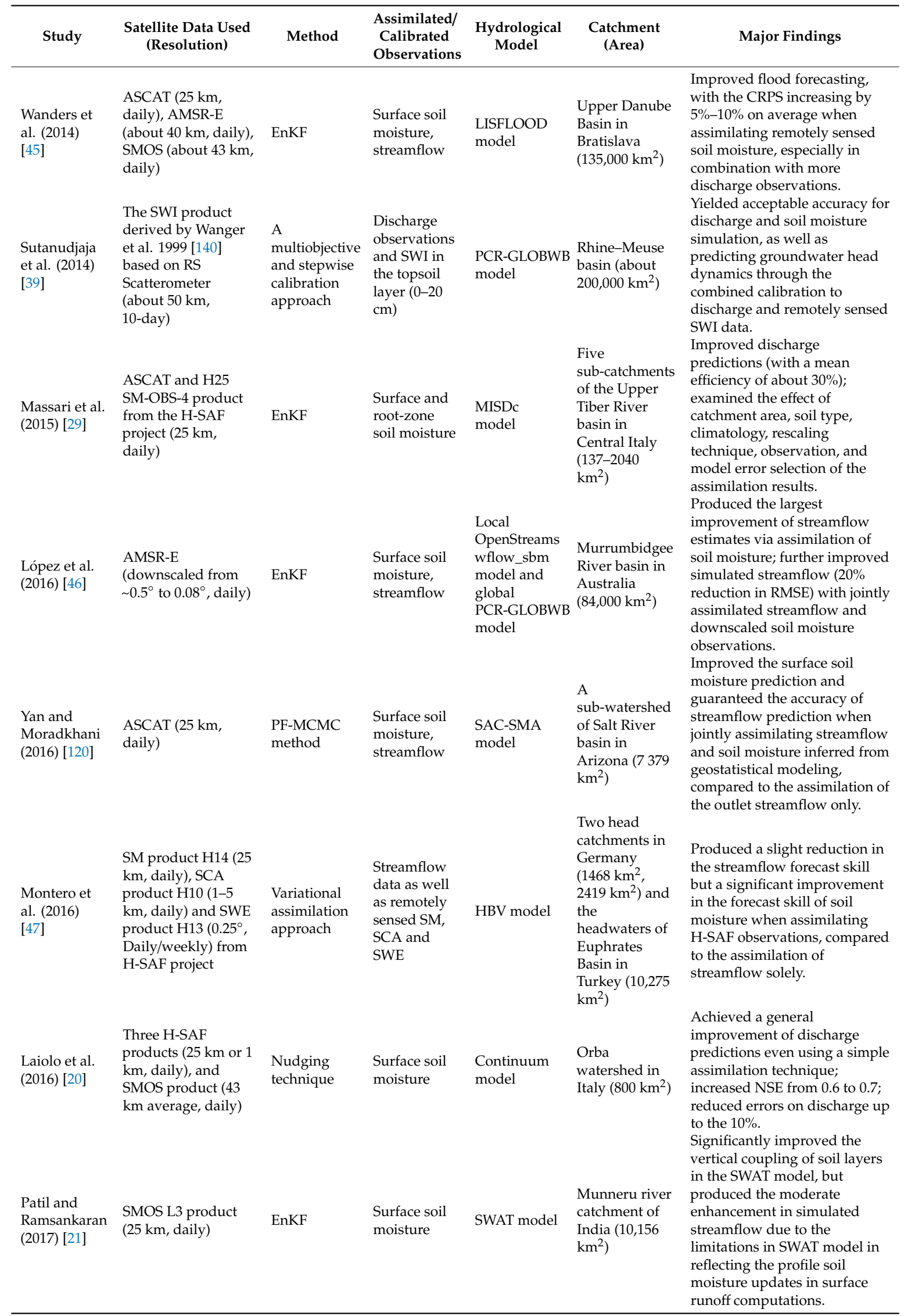


Table 3. Cont.

\begin{tabular}{|c|c|c|c|c|c|c|}
\hline Study & $\begin{array}{l}\text { Satellite Data Used } \\
\text { (Resolution) }\end{array}$ & Method & $\begin{array}{l}\text { Assimilated/ } \\
\text { Calibrated } \\
\text { Observations }\end{array}$ & $\begin{array}{l}\text { Hydrological } \\
\text { Model }\end{array}$ & $\begin{array}{l}\text { Catchment } \\
\text { (Area) }\end{array}$ & Major Findings \\
\hline $\begin{array}{l}\text { Zhang et al. } \\
\text { (2017) [48] }\end{array}$ & $\begin{array}{l}\text { Not clear soil } \\
\text { moisture data, } \\
\text { possibly from SMOS } \\
\text { and SMAP }\end{array}$ & EnKF & $\begin{array}{l}\text { Soil } \\
\text { moisture, } \\
\text { SWE, and } \\
\text { discharge }\end{array}$ & $\begin{array}{l}\text { SWATGP } \\
\text { model }\end{array}$ & $\begin{array}{l}\text { Babaohe River } \\
\text { Basin of China } \\
\left(2455 \mathrm{~km}^{2}\right)\end{array}$ & $\begin{array}{l}\text { Improved the estimates of } \\
\text { hydrological states by the } \\
\text { presented SWAT-HDAS system } \\
\text { using soil } \\
\text { moisture/snow/discharge } \\
\text { observation data, but the } \\
\text { application of soil moisture and } \\
\text { SWE observations may } \\
\text { degrade streamflow estimates } \\
\text { when discharge observations } \\
\text { have been assimilated. }\end{array}$ \\
\hline $\begin{array}{l}\text { Patil and } \\
\text { Ramsankaran } \\
(2018)[124]\end{array}$ & $\begin{array}{l}\operatorname{SMOS}\left(0.25^{\circ}, \text { daily) }\right. \\
\text { and ASCAT }\left(0.25^{\circ} \text {, }\right. \\
\text { daily) }\end{array}$ & EnKF & $\begin{array}{l}\text { Surface and } \\
\text { root zone } \\
\text { soil moisture }\end{array}$ & SWAT model & $\begin{array}{l}\text { Wyra } \\
\text { catchment } \\
\left(1650 \mathrm{~km}^{2}\right) \\
\text { and Varada } \\
\text { catchment } \\
\left(5092 \mathrm{~km}^{2}\right) \text { in } \\
\text { India }\end{array}$ & $\begin{array}{l}\text { Moderately improved surface } \\
\text { runoff, lateral flows, } \\
\text { groundwater flows, and } \\
\text { streamflow using the proposed } \\
\text { SMAR-EnKF scheme for } \\
\text { updating profile soil moisture. }\end{array}$ \\
\hline $\begin{array}{l}\text { Loizu et al. } \\
\text { (2018) [15] }\end{array}$ & $\begin{array}{l}\text { ASCAT product ( } 25 \\
\mathrm{~km} \text {, daily) }\end{array}$ & EnKF & $\begin{array}{l}\text { Surface soil } \\
\text { moisture } \\
\text { (SSM) }\end{array}$ & $\begin{array}{l}\text { MISDc and } \\
\text { TOPLATS } \\
\text { model }\end{array}$ & $\begin{array}{l}\text { Nestore } \\
\text { catchment }(725 \\
\left.\mathrm{km}^{2}\right) \text { and Arga } \\
\text { catchment }(810 \\
\left.\mathrm{km}^{2}\right) \text { in Spain }\end{array}$ & $\begin{array}{l}\text { Improved simulated } \\
\text { streamflow, which NSE } \\
\text { increased by } 10 \%-45 \% \text { from the } \\
\text { validation run and } 6 \%-35 \% \\
\text { from the open-loop simulation, } \\
\text { with the variation depending } \\
\text { largely on the catchment } \\
\text { characteristics, the assumed } \\
\text { SSM observation error, and the } \\
\text { selected re-scaling technique. }\end{array}$ \\
\hline $\begin{array}{l}\text { Li et al. } \\
(2018)[40]\end{array}$ & $\begin{array}{l}\text { SMOS ( 45 km, 1-3 } \\
\text { day) }\end{array}$ & $\begin{array}{l}\text { A joint } \\
\text { calibration } \\
\text { scheme }\end{array}$ & $\begin{array}{l}\text { Gauged } \\
\text { streamflow } \\
\text { and } \\
\text { near-surface } \\
\text { soil moisture }\end{array}$ & $\begin{array}{l}\text { GRKAL } \\
\text { model }\end{array}$ & $\begin{array}{l}\text { Clarence River } \\
\text { catchment } \\
\text { upstream of } \\
\text { Lilydale and } \\
\text { Condamine } \\
\text { River } \\
\text { catchment } \\
\text { upstream of } \\
\text { Chinchilla in } \\
\text { Australia }\end{array}$ & $\begin{array}{l}\text { Compared with streamflow } \\
\text { only calibration, it slightly } \\
\text { degraded the streamflow } \\
\text { simulation at gauged sites } \\
\text { during the calibration period } \\
\text { but obtained improvements at } \\
\text { the same gauged sites during } \\
\text { the independent validation } \\
\text { period and a more consistent } \\
\text { and statistically significant } \\
\text { improvement at the gauged } \\
\text { sites, which were not used in } \\
\text { the calibration. }\end{array}$ \\
\hline $\begin{array}{l}\text { Leach et al. } \\
\text { (2018) [49] }\end{array}$ & $\begin{array}{l}\text { SMOS-SM data (43 } \\
\text { km, daily) and } \\
\text { SNODAS-SWE data } \\
\text { (1 km, daily) }\end{array}$ & EnKF & $\begin{array}{l}\text { Soil } \\
\text { moisture, } \\
\text { SWE and } \\
\text { streamflow } \\
\text { observations }\end{array}$ & $\begin{array}{l}\text { GR4J, } \\
\text { HYMOD, } \\
\text { MAC-HBV, } \\
\text { and } \\
\text { SAC-SMA } \\
\text { models }\end{array}$ & $\begin{array}{l}\text { Highly-urbanized } \\
\text { Don River } \\
\text { basin in } \\
\text { Canada (350 } \\
\mathrm{km}^{2} \text { ) }\end{array}$ & $\begin{array}{l}\text { Produced some improvement } \\
\text { to different aspects of } \\
\text { hydrologic simulation and } \\
\text { forecasting when jointly } \\
\text { assimilating soil moisture and } \\
\text { SWE. }\end{array}$ \\
\hline
\end{tabular}

Abbreviations: ERS, European Remote Sensing Satellites; TOPLATS, TOPMODEL-based Land-Atmosphere Transfer Scheme; EnKF, ensemble Kalman filter; EnKS, ensemble Kalman smoother; SWI, Soil Water Index; BibModel, a numerical model which incorporates the dominant hydrological processes in the Bibeschbach catchment; MISDc, Modello Idrologico Semi-Distribuito in continuo; RZSM, root-zone soil moisture; ECMWF, European Centre for Medium-Range Weather Forecasts; Six catchments, included two catchments in central Italy (Niccone, $137 \mathrm{~km}^{2}$ and Assino,165 $\mathrm{km}^{2}$ ), one in South Italy (Fiumarella, $33 \mathrm{~km}^{2}$ ), one in Luxembourg (Bibeschbach, $12 \mathrm{~km}^{2}$ ), one in France (Valescure, $3.7 \mathrm{~km}^{2}$ ), and one in US (Lucky Hills, $0.001 \mathrm{~km}^{2}$ ); LISFLOOD, a GIS-based distributed model for river basin scale water balance and flood simulation; CRPS, continuous ranked probability score; PCR-GLOBWB, PCRaster Global Water Balance; PF-MCMC, Particle Filter-Markov Chain Monte Carlo method; SM, soil moisture; Three H-SAF products, included SM OBS 1-H07 $(25 \mathrm{~km})$, SM OBS 2-H08 (1 km) and SM DAS 2-H14 (25 km), which were derived from ASCAT observations; SCA, snow covered area; SWE, snow water equivalent; SWATGP, a gridded and parallelized SWAT model [146]; SWAT-HDAS, integration of the gridded and parallelized SWAT model (SWATGP) and the Parallel Data Assimilation Framework (PDAF); SMAR-EnKF, SMAR was used for estimating root zone soil moisture from surface measurements, coupled with EnKF; GRKAL, a new version of GRHUM, which two independent near-surface and root-zone soil moisture layers are parameterized and the drainage from the near-surface layer is used as the input for the root-zone layer; GRHUM, the soil water storage of the GR4J reparametrized into a two layer system of the near-surface soil moisture layer and the bulk soil moisture layer; GR4J, modèle du Génie Rural à 4 paramètres Journalier; SNODAS, Snow Data Assimilation System; HYMOD, HYdrologic MODel; MAC-HBV, McMaster University-HBV. 


\subsection{Remotely Sensed Snow Observations}

In mid-altitude and high-altitude catchments, snowmelt can contribute largely to runoff, owing to its influences on water storage and surface albedo [147-149]. Snowmelt accounts for about $70 \%-80 \%$ of the total annual runoff in such regions of the northern United States [150]. Therefore, the accurate estimate of snowmelt is important for streamflow predictions in these regions, especially in mountainous areas $[149,150]$. Some studies have shown that assimilating snow observations, such as SWE, Snow Depth (SD), and SCA, into a hydrologic model could achieve improved streamflow estimates [151-156]. This improvement was more notable in poorly calibrated basins than basins with a relatively higher calibrated model performance [154].

In recent years, remotely-sensed snow observations have been increasingly taken account for streamflow estimates in snow-dominated areas because of their increasing spatial resolution, reasonable spatiotemporal continuity, and relatively short latency [155]. SCA can be measured using optical sensors, such as Advanced Very High Resolution Radiometer (AVHRR), MODIS, and the Interactive Multisensor Snow and Ice Mapping System (IMS), which have high spatial resolutions [157]. These sensors can exploit the high reflectance of snow-covered areas in comparison with areas without snow cover but are limited to cloud-free conditions [158,159]. Active microwave sensors, such as RADARSAT Synthetic Aperture Radar (SAR), ENVironmental monitoring SATellite Advanced SAR (Envisat ASAR), and Terra SAR-X, can also detect snow-cover characteristics, but they are only able to reliably recognize wet snow $[157,160]$. SD or SWE can be retrieved via microwave technologies, especially passive microwave (PM) sensors, such as Scanning Multichannel Microwave Radiometer (SMMR), Special Sensor Microwave Imager (SSM/I), and AMSR-E $[55,161]$. Compared with active sensors, PM sensors have a coarser spatial resolution and lower accuracy in regions with dense vegetation cover and proximity to open water. They are also prone to signal saturation in regions with deep snowpacks but can produce accurate observations under cloudy and nighttime conditions [159,162].

Assimilating these satellite-based snow observations can potentially lead to improved snow predictions and improved streamflow predictions (e.g., [151,156]). However, this improvement is limited mainly to the snowmelt season $[147,153]$. Moreover, some studies have reported that snow data assimilation had limited success for streamflow simulations (e.g., [47,161,163]). For example, Kumar et al. (2014) [161] found that the assimilation of SD datasets from SMMR, SSM/I, and AMSR-E, which was augmented with in situ meteorological station-based measurements, improved the snow fields but did not always translate to corresponding improvements in streamflow. This was mainly caused by the low skill of PM-based retrievals, as mentioned above [161,162]. Bergeron et al. (2016) [153] reported that the assimilation against SCA data from MODIS yielded little or no improvement for all state variables and even a strong deterioration in most cases, compared to the open-loop scenario. The most probable factor for this result was the absence of SCA as a state variable or a proxy with a great enough linear relationship to SCA [153].

In light of the unsatisfactory results obtained from assimilating the single snow variable, there are studies on integrating multi-source or multi-variable snow observations to improve streamflow predictions. For instance, Kumar et al. (2015) [159] examined the approach of using SCA observations from MODIS and IMS as additional snow detection constraints in PM-based SD data assimilation. Their results showed that the SCA-based constraint, especially with the use of MODIS datasets, not only effectively improved estimates of snow depth, but also enhanced simulated streamflow, despite only small improvements. Liu et al. (2015) [155] found that the integration of SD data from AMSR-E, and in-situ observations from the Snow Telemetry (SNOTEL) networks located at high altitudes, along with the terrain aspect, could improve snow predictions and produce reliable streamflow predictions. Incorporating SCA data from MODIS could further improve the streamflow results slightly [155].

In addition, some studies have explored the effect of the joint assimilation of snow and other variables (e.g., streamflow, soil moisture) on the performance of streamflow predictions. Leach et al. (2018) [49] found that the assimilation of remote-sensed soil moisture and SWE data into different hydrological models improved hydrologic modeling and forecasting in the highly-urbanized Don 
River basin $\left(350 \mathrm{~km}^{2}\right)$. However, a study by Montero et al. (2016) [47] showed that the assimilation of soil moisture, SWE, and SCA from H-SAF observations slightly reduced the streamflow forecast skill compared to the assimilation of streamflow data alone. To sum up, snow data has a limited ability to enhance streamflow estimates, but an improved state of SWE may contribute more accurate information for the available water for the snowmelt, which is crucial for runoff prediction during the snowmelt season [152].

\subsection{Remotely Sensed TWSC Data}

Remotely sensed TWSC from GRACE have been also used to improve hydrological modeling (e.g., [53,164,165]). For instance, Chen et al. (2017) [53] reported that the joint application of remotely sensed SCA, SWE, and TWSC, with streamflow observations in the hydrological model's calibration, provided more reliable streamflow, snow (both SCA and SWE), and TWSC simulations than the calibration based on streamflow and/or SCA performance. However, several studies have demonstrated that the improvement in streamflow estimates using GRACE-derived TWSC data was modest rather than significant (e.g., $[164,165])$. In addition, some studies showed that the GRACE assimilation could not enhance or might even degrade the performance of streamflow simulations $[41,166,167]$. For instance, Bai et al. (2018) [41] discovered that incorporating GRACE data into the model calibration, along with the runoff observations, achieved more reliable TWSC and ET simulations but slightly reduced the accuracy of streamflow simulations compared to the traditional single-objective calibration. Overall, GRACE-derived TWSC data show great limitations in improving hydrological simulations, especially in small catchments, as these data cannot help to capture high flow events because of their coarse temporal and spatial resolution (monthly, $1^{\circ} \times 1^{\circ}$ respectively) $[167,168]$. Nevertheless, these data can still provide candidate complementary data to better constrain parameterizations of hydrological models in conjunction with streamflow observations [41].

\subsection{Remotely Sensed Land Surface Temperature}

Land Surface Temperature (LST) is the connection between water and energy balances. LST derived from polar orbiting or geostationary satellites can be used to calibrate the hydrological model [44]. Moreover, the calibration procedure based on satellite-based LST alone may outperform the calibration based on discharge [169]. However, most studies reported that calibrations against satellite-derived LST data, evenly combined with streamflow observations, produced poorer performance for streamflow simulations [44,170,171]. Probably, the application of LST is more suitable for large-scale catchments $[169,170]$. Nevertheless, LST can be helpful to constrain model parameters in the calibration process and reduce parametric uncertainty, compared to streamflow only calibration $[44,170,171]$.

\subsection{Remotely Sensed River Width}

In ungauged basins lacking any ground observations, satellite observations of river width can be used as a surrogate to represent streamflow variations and be applied to hydrological model calibration [172]. Even river discharge can be estimated exclusively using satellite-derived parameters (e.g., river width, water depth, flow velocity) [173-176]. For example, Gleason and Smith (2014) [174] proposed a satellite-only AMHG (at-many-stations hydraulic geometry) discharge retrieval method. This method, based solely on Landsat Thematic Mapper images observations of instantaneous river surface width, yielded river discharge agreeing to within $20 \%-30 \%$ of in situ observations. Moreover, the AMHG method can also address global discharge knowledge gaps solely from repeat satellite imagery [175]. Overall, promising results of streamflow retrievals from satellite observations of river hydraulic variables have been reported in large continental rivers with river widths exceeding $100 \mathrm{~m}$. However, they have not been applied to smaller regional rivers. More importantly, satellite-based streamflow retrievals cannot achieve the accuracy of in situ observations and should not be treated as a gauge replacement strategy [176-178]. 


\section{The Application of Data Assimilation for Merging Satellite-Based Remote Sensing with a Hydrological Model}

Data assimilation (DA) techniques have been widely and increasingly applied in hydrological studies $[108,119,120,125,130,179]$. Particularly, DA shows superiority in integrating multiple observation types into hydrological models $[45,46,49,120,121]$. DA can not only update the hydrological state variables and model parameters (simultaneously seeking the best model state and parameters to enhance model performance) but also can account for and reduce various sources of uncertainties in both the models and the assimilated data products $[21,49,108,179,180]$. Some studies have indicated that, overall, the assimilation of observed data, even poor or coarse data, could produce at least a slight improvement compared to the open-loop run (no DA) [20,21,130,181-183].

Early studies of data assimilation in hydrology focused on the application of soil moisture in land surface models $[119,184-186]$. Further, streamflow or $\mathrm{ET}_{\mathrm{a}}$ data have been assimilated into hydrological models, offering promising results $[108,119,187,188]$. Recently, the potential of observed data such as SWE, SCA, and TWSC in hydrological predictions has been investigated, illustrating both positive and negative results $[148,153,154,164,166]$. In addition, multiple observation data types have been also assimilated into hydrological models, thereby achieving better performance in model predictions [32,46,119,121,189]. For instance, Yan and Moradkhani (2016) [120] found that the joint assimilation of remote-sensing surface soil moisture and streamflow significantly reduced RMSE relative to the assimilation of the outlet streamflow solely. Xiong et al. (2019) [32] demonstrated that the time-varying model parameters (evapotranspiration parameter and water storage capacity) gained by adding $\mathrm{ET}_{\mathrm{a}}$ data into the assimilation with streamflow resulted in a significant improvement in deterministic streamflow and ET simulation, compared to the separate assimilation of streamflow, with time invariant approaches.

The main data assimilation techniques used to combine remotely sensed data with hydrological models include the Kalman filter and its variants, particle filters (PF), and variational methods $[15,119]$. Each technique has its own advantages and weaknesses [190,191]. Among them, the ensemble Kalman filter (EnKF) is the most widely used technique in hydrology [21,48,108,119,121,142,179,185,192], because it can not only account for nonlinearities (and partially nonGaussianity) with few restrictive assumptions $[119,188]$, but can also continuously update hydrological state variables and parameters when new measurements are available with simple implementation $[108,119]$. It can also flexibly represent various uncertainties in simulations and observations [21,28,119]. However, EnKF assumes a Gaussian distribution in model errors, which may lead to degeneration when the size of the state space is much larger than the ensemble size $[119,121]$. In addition, the stationary parameter assumption within EnKF is challenged under climate and land use change [120,193,194]. These deficiencies may weaken the superiority of EnKF $[120,179,195,196]$. In contrast, Particle Filters (PFs) can relax the Gaussian assumption of error distributions $[120,179,191]$ and more completely represent state/parameter posterior distribution for a given nonlinear and non-Gaussian system [120,179]. Hence, PF is considered to be a more robust DA technique for hydrological studies $[120,180,196-198]$ and has received increasing attention as an effective tool to improve model predictions [179]. However, PF commonly requires more samples than other DA methods and, hence, may impose an obvious computational burden for achieving accurate results [191,199]. Besides, PF shows one potential limitation in terms of the particle degeneracy that the particles lose their ability to correctly approximate the posterior distribution [179].

Given these concerns, some researchers have explored new assimilation schemes based on popular DA techniques for better assimilation performance [48,125,179,191,200]. For example, Andrieu et al. (2010) [200] proposed the PF-MCMC technique to reduce weight degeneracy within the PF. Then, Abbaszadeh et al. (2018) [179] presented the Evolutionary PF-MCMC (EPFM) to characterize a more accurate and reliable posterior distribution for state variables of interest in data assimilation applications. Meng et al. (2017) [125] established an effective data assimilation scheme based on the Ensemble Kalman Filter and Smoother (named EnKF-S) by accounting for the runoff routing lag between streamflow and soil moisture, which 
has been rarely considered in most studies. To overcome the shortcomings in EnKF and PF, Fan et al. (2017) [191] developed two integrated data assimilation schemes, i.e., the coupled EnKF and PF (CEnPF) and parallelized EnKF and PF (PEnPF) approaches, which provided better results for both deterministic and probabilistic predictions than traditional EnKF and PF approaches. Overall, these new DA methods have made contributions to obtain better hydrological predictions. However, their practicability and feasibility also need further verification.

In additional, it should be noted that the unconstrained implementation of DA to the model output may result in model states beyond physically realistic limits, and, conversely, physical limits can be controlled by using constraints $[28,142,201,202]$. Hence, a strongly-constrained (SC) DA approach has been proposed to account for errors in the model's initial and boundary conditions, as well as model parameters to improve the fit of the model to the observations [203]. However, this SC DA approach ignores the model error, and, hence, updated states may be over-adjusted in order to compensate for model errors [142,167]. In contrast, a weakly-constrained (WC) DA approach has been developed, which can account for model structural errors with less adjustment to state variables and can achieve analyses that are similar to, or more accurate than, the SC DA results [201]. Lee et al. (2016) [201] found that, compared to the SC DA approach, assimilating outlet streamflow using the WC DA approach resulted in a larger correlation between the a priori and updated states and produced similar or reduced RMSE of streamflow analysis and prediction. However, Maxwell et al. (2018) [142] reported that these mass constraints, more commonly applied to ensure that the non-negativity and capacity thresholds of model states were not exceeded, did little to improve forecast performance relative to the unconstrained and free run model outputs. In contrast, the combination of mass and flux constrained assimilation can improve the accuracy and reliability of streamflow predictions [142].

In general, a great number of studies have proved the potential of DA to effectively compensate for inaccurate estimations, substantially improving hydrological forecasting and explicitly dealing with various uncertainties (from model forcing data, model parameters, model structures, model initial and boundary conditions, etc.) (e.g., $[21,28,108,125,179,191])$. However, differences in the selected DA technique or its expansion, the hydrological model, the assimilated observation type, data availability, the specification and quantification of the model and observation errors, basin characteristics, and constrained or unconstrained DA would exert an effect on the performance of streamflow predictions $[15,20,29,120,141,142]$. Hence, the optimal selection of appropriate settings within a DA system based on catchment characteristics and data availability is crucial to provide less uncertain and more reliable forecast model outputs.

\section{Summaries, Discussions, and Outlooks}

In conclusion, the application of satellite-based remote sensing to improve streamflow predictions has received increasing attention. The popular observation variables mainly include precipitation, soil moisture, $\mathrm{ET}_{\mathrm{a}}$, SWE, SCA, TWSC, LST, and river width. Among them, SREs have been scarcely used within hydrological modeling, because they are generally inferior in driving hydrological models to ground observations. There are many reports about using satellite-based $\mathrm{ET}_{\mathrm{a}}$ to enhance $\mathrm{ET}_{\mathrm{a}}$ estimation itself, but few have aimed at improving streamflow simulations, because $\mathrm{ET}_{\mathrm{a}}$ is not a state variable of hydrological models and is difficult to measure. For remotely sensed SWE and SCA, a number of studies have examined their utility in improving runoff estimations. Some findings have demonstrated improvements in both snow and streamflow predictions through using remotely-sensed snow observations. However, their limited contributions to, and even degradations in, the ability of streamflow simulations have been also reported. In terms of TWSC, relevant studies using GRACE-derived TWSC data to produce better streamflow estimation have been seldom mentioned. Moreover, in most cases, only modest or poor improvements have been obtained, mainly due to the low temporal and spatial resolutions of GRACE-derived TWSC data. The utility of LST and river width provided good to poor model performance. Furthermore, their applications seem to be more 
appropriate for large-scale catchments. Particularly, river width is unable to replace in situ observations, which is limited only to ungauged basins.

In contrast, more studies focused on applying remote sensing soil moisture products to improve simulated streamflow because of the important role of soil moisture in runoff generations. In early studies, satellite-based surface soil moisture was integrated into hydrological models, and, then, the root zone soil moisture was estimated and applied to the models to attain more accurate hydrological predictions. Moreover, several studies have employed the highest vertical error correlation in different soil layers for updating the subsurface soil moisture in surface runoff estimates. In addition, many studies have jointly used both soil moisture and streamflow (and/or snow data and TWSC data) to achieve better performance for hydrological forecasting. Meanwhile, new assimilation or calibration schemes have been developed, and different constraints to the data assimilation have been implemented to improve assimilation performance.

Overall, the aforementioned studies have made great contributions to hydrological modeling improvement through using satellite-based remote sensing. However, these results have shown more or less of a difference, owing to the differences in the selected hydrological model, catchment characteristics, assimilation or calibration procedures, and satellite-based observations. Thus, how to choose and apply remote sensing data to provide better streamflow estimates should be regarded cautiously, particularly in complex watersheds controlled by high-intensity human activities. For instance, in the Dagu River basin, located in the Shandong peninsula of China, river runoff has been almost zero, and some river reaches have dried up in the non-flood period over the past several decades [204]. Even in some dry years, the Dagu River might have been cut off over an entire year. This was mainly attributed to intense human activities, particularly water interception by cascade dams for human water consumption. Cascade dams separated the Dagu River into many similar long narrow lakes, which resulted in hydrological connectivity almost vanishing. Limited streamflow observations failed to provide sufficient information for judging the accuracy of hydrological modeling. Therefore, it will be a challenge to simulate hydrological processes in similar watersheds.

The application of satellite-based observations may help to achieve better model results. In light of this goal, a framework is recommended to help apply remotely sensed observations to improve hydrological modeling in highly regulated basins (the Dagu River basin, for instance). First, the information of land use/land cover (LULC) can be interpreted using high-spatial-resolution remote sensing data, such as Landsat images $(30 \mathrm{~m})$, Sentinel $2(10 \mathrm{~m})$, and GF-2 $(1 \mathrm{~m}, 4 \mathrm{~m})$. As one of the most important inputs into hydrological models, high precision LULC data can improve the simulation of the impact of human activity on hydrological cycles. Second, remotely-sensed soil moisture and $\mathrm{ET}_{\mathrm{a}}$ can be jointly used in hydrological models, which were rarely reported in early studies. Better hydrological predictions can be achieved by comparing different simulation results from using remotely-sensed soil moisture, $\mathrm{ET}_{\mathrm{a}}$, or streamflow observations alone, as well as their respective combinations. Third, data assimilation and model calibration can be employed to extract useful information from remotely-sensed soil moisture and $\mathrm{ET}_{\mathrm{a}}$. Their contributions to hydrological estimations can be evaluated and compared to seek better model performance. In addition, ML approaches, such as ANNs and SVM, can be attempted to represent the complex and non-linear dynamics inherent to hydrological processes, complementary to hydrological models. Finally, the available data concerning cascade dams and water consumption can be added to hydrological models prior to parameter calibration or data assimilation to improve hydrological modeling. Generally, this framework may be a functional solution for hydrological modeling in human-dominated watersheds. In the future, it will be necessary to implement relevant studies to verify this framework's feasibility and effectiveness over highly regulated basins.

Encouragingly, the new development of remote sensing technologies, especially the new launch of satellites, has great potential to improve estimates of relevant hydrological variables for hydrological modeling, in terms of accuracy, resolution, and repeat times. For example, the Water Cycle Observation Mission (WCOM) will provide synergetic observations for key global water cycle parameters, which are focused on soil moisture, snow water equivalents, and freeze/thaw [205]. The second, third, and 
fourth spacecraft of the Joint Polar Satellite System (JPSS), JPSS-2, JPSS-3 and JPSS-4, will be launched in 2021, 2026, and 2031 respectively. These spacecraft will offer daily time series for retrievals of LST and ET, as well as vegetation parameters and snow cover products [55]. Several hyperspectral missions are planned, which can help to improve snow retrieval, vegetation monitoring, and ET estimates $[55,206]$. These upcoming missions would also benefit improvements of streamflow predictions, despite new, emerging challenges.

Author Contributions: Initiation of the original idea of the paper, D.J.; writing—original draft preparation, D.J.; writing-review and editing, D.J. and K.W.

Funding: This research was funded by the Key R\&D Program of China, grant number 2017YFD0300402 and the National Natural Science Foundation of China, grant number 41701495 and 40901028.

Conflicts of Interest: The authors declare no conflict of interest.

\section{References}

1. Wang, B.L.; Zhang, H.T.; Liang, X.; Li, X.D.; Wang, F.S. Cumulative effects of cascade dams on river water cycle: Evidence from hydrogen and oxygen isotopes. J. Hydrol. 2019, 568, 604-610. [CrossRef]

2. Wang, X.B.; He, K.N.; Dong, Z. Effects of climate change and human activities on runoff in the Beichuan River Basin in the northeastern Tibetan Plateau, China. CATENA 2019, 176, 81-93. [CrossRef]

3. Zhang, X.; Zhang, L.; Zhao, J.; Rustomji, P.; Hairsine, P. Responses of streamflow to changes in climate and land use/cover in the Loess Plateau, China. Water Resour. Res. 2008, 44, 2183-2188. [CrossRef]

4. Bao, Z.X.; Zhang, J.Y.; Wang, G.Q.; Fu, G.B.; He, R.M.; Yan, X.L.; Jin, J.L.; Liu, Y.L.; Zhang, A.J. Attribution for decreasing streamflow of the Haihe River basin, northern China: Climate variability or human activities? J. Hydrol. 2012, 460-461, 117-129. [CrossRef]

5. Li, L.J.; Jiang, D.J.; Hou, X.Y.; Li, J.Y. Simulated runoff responses to land use in the middle and upstream reaches of Taoerhe River basin, Northeast China, in wet, average and dry years. Hydrol. Process. 2013, 27, 3484-3494. [CrossRef]

6. Kim, T.W.; Kim, D.; Baek, S.H.; Kim, Y.K. Human and riverine impacts on the dynamics of biogeochemical parameters in Kwangyang Bay, South Korea revealed by time-series data and multivariate statistics. Mar. Pollut. Bull. 2015, 90, 304-311. [CrossRef] [PubMed]

7. Wang, H.; Jia, Y.W. Theory and study methodology of dualistic water cycle in river basins under changing conditions. J. Hydraul. Eng. 2016, 47, 1219-1226. (In Chinese)

8. Li, B.; Li, C.Y.; Liu, J.Y.; Zhang, Q.; Duan, L.M. Decreased Streamflow in the Yellow River Basin, China: Climate Change or Human-Induced? Water 2017, 9, 116. [CrossRef]

9. Han, Q.; Wang, B.; Liu, C.Q.; Wang, F.; Peng, X.; Liu, X.L. Carbon biogeochemical cycle is enhanced by damming in a karst river. Sci. Total Environ. 2018, 616-617, 1181-1189. [CrossRef]

10. Kirwan, M.L.; Megonigal, J.P. Tidal wetland stability in the face of human impacts and sea-level rise. Nature 2013, 504, 53-60. [CrossRef]

11. Sreeja, K.G.; Madhusoodhanan, C.G.; Eldho, T.I. Coastal zones in integrated river basin management in the West Coast of India: Delineation, boundary issues and implications. Ocean Coast. Manag. 2016, 119, 1-13. [CrossRef]

12. Hyfield, E.C.G.; Day, J.W.; Cable, J.E.; Justic, D. The impacts of re-introducing Mississippi River water on the hydrologic budget and nutrient inputs of a deltaic estuary. Ecol. Eng. 2008, 32, 347-359. [CrossRef]

13. Flemer, D.A.; Champ, M.A. What is the future fate of estuaries given nutrient over-enrichment, freshwater diversion and low flows. Mar. Pollut. Bull. 2006, 52, 247-258. [CrossRef] [PubMed]

14. Yaghmaei, H.; Sadeghi, S.H.; Moradi, H.; Gholamalifard, M. Effect of dam operation on monthly and annual trends of flow discharge in the Qom Rood Watershed, Iran. J. Hydrol. 2018, 557, 254-264. [CrossRef]

15. Loizu, J.; Massari, C.; Álvarez-Mozos, J.; Tarpanelli, A.; Brocca, L.; Casalí, J. On the assimilation set-up of ASCAT soil moisture data for improving streamflow catchment simulation. Adv. Water Resour. 2018, 111, 86-104. [CrossRef]

16. Khaki, M.; Hoteit, I.; Kuhn, M.; Forootan, E.; Awange, J. Assessing data assimilation frameworks for using multi-mission satellite products in a hydrological context. Sci. Total Environ. 2019, 647, 1031-1043. [CrossRef] [PubMed] 
17. Zhang, Y.R.; Sun, A.; Sun, H.W.; Gui, D.W.; Xue, J.; Liao, W.H.; Yan, D.; Zhao, N.; Zeng, X.F. Error adjustment of TMPA satellite precipitation estimates and assessment of their hydrological utility in the middle and upper Yangtze River Basin, China. Atmos. Res. 2019, 216, 52-64. [CrossRef]

18. Refsgaard, J.C.; Knudsen, J. Operational validation and intercomparison of different types of hydrological models. Water Resour. Res. 1996, 32, 2189-2202. [CrossRef]

19. Niraula, R.; Meixner, T.; Norman, L.M. Determining the importance of model calibration for forecasting absolute/relative changes in streamflow from LULC and climate changes. J. Hydrol. 2015, 522, 439-451. [CrossRef]

20. Laiolo, P.; Gabellani, S.; Campo, L.; Silvestro, F.; Delogu, F.; Rudari, R.; Pulvirenti, L.; Boni, G.; Fascetti, F.; Pierdicca, N.; et al. Impact of different satellite soil moisture products on the predictions of a continuous distributed hydrological model. Int. J. Appl. Earth. Obs. 2016, 48, 131-145. [CrossRef]

21. Patil, A.; Ramsankaran, R. Improving streamflow simulations and forecasting performance of SWAT model by assimilating remotely sensed soil moisture observations. J. Hydrol. 2017, 555, 683-696. [CrossRef]

22. Khan, U.; Ajami, H.; Tutej, N.K.; Sharma, A.; Kim, S. Catchment scale simulations of soil moisture dynamics using an equivalent cross-section based hydrological modelling approach. J. Hydrol. 2018, 564, 944-966. [CrossRef]

23. Manjula, D.; Dhanya, C.T. How important is heterogeneous parameter distribution in capturing the catchment response through hydrologic modelling? In Proceedings of the 19th EGU General Assembly, EGU2017, Vienna, Austria, 23-28 April 2017; p. 818.

24. Ajami, N.K.; Duan, Q.; Sorooshian, S. An integrated hydrologic Bayesian multimodel combination framework: Confronting input, parameter, and model structural uncertainty in hydrologic prediction. Water Resour. Res. 2007, 43, W01403. [CrossRef]

25. Immerzeel, W.W.; Droogers, P. Calibration of a distributed hydrological model based on satellite evapotranspiration. J. Hydrol. 2008, 349, 411-424. [CrossRef]

26. Gupta, H.V.; Clark, M.P.; Vrugt, J.A.; Abramowitz, G.; Ye, M. Towards a comprehensive assessment of model structural adequacy. Water Resour. Res. 2012, 48, W08301. [CrossRef]

27. Vrugt, J.A.; ter Braak, C.J.F.; Diks, C.G.H.; Schoups, G. Advancing hydrologic data assimilation using particle Markov chain Monte Carlo simulation: theory, concepts and applications. Adv. Water Resour. 2013, 51, 457-478. [CrossRef]

28. Xie, X.; Meng, S.; Liang, S.; Yao, Y. Improving streamflow predictions at ungauged locations with real-time updating: application of an EnKF-based state-parameter estimation strategy. Hydrol. Earth Syst. Sci. 2014, 18, 3923-3936. [CrossRef]

29. Massari, C.; Brocca, L.; Tarpanelli, A.; Moramarco, T. Data assimilation of satellite soil moisture into rainfall-runoff modelling: A complex recipe? Remote Sens. 2015, 7, 11403-11433. [CrossRef]

30. Liu, D.; Mishra, A.K. Performance of AMSR_E soil moisture data assimilation in CLM4.5 model for monitoring hydrologic fluxes at global scale. J. Hydrol. 2017, 547, 67-79. [CrossRef]

31. Hartanto, I.M.; van der Kwast, J.; Alexandridis, T.K.; Almeida, W.; Song, Y.; van Andel, S.J.; Solomatine, D.P. Data assimilation of satellite-based actual evapotranspiration in a distributed hydrological model of a controlled water system. Int. J. Appl. Earth. Obs. 2017, 57, 123-135. [CrossRef]

32. Xiong, M.S.; Liu, P.; Cheng, L.; Deng, C.; Gui, Z.L.; Zhang, X.J.; Liu, Y.H. Identifying time-varying hydrological model parameters to improve simulation efficiency by the ensemble Kalman filter: A joint assimilation of streamflow and actual evapotranspiration. J. Hydrol. 2019, 568, 758-768. [CrossRef]

33. Shortridge, J.E.; Guikema, S.D.; Zaitchik, B.F. Machine learning methods for empirical streamflow simulation: a comparison of model accuracy, interpretability, and uncertainty in seasonal watersheds. Hydrol. Earth Syst. Sci. 2016, 20, 2611-2628. [CrossRef]

34. Solomatine, D.P.; Ostfeld, A. Data-driven modelling: some past experiences and new approaches. J. Hydroinform. 2008, 10, 3-22. [CrossRef]

35. Abrahart, R.J.; See, L.M. Neural network modelling of nonlinear hydrological relationships. Hydrol. Earth Syst. Sci. 2007, 11, 1563-1579. [CrossRef]

36. Tian, Y.; Xu, Y.P.; Yang, Z.L.; Wang, G.Q.; Zhu, Q. Integration of a Parsimonious Hydrological Model with Recurrent Neural Networks for Improved Streamflow Forecasting. Water 2018, 10, 1655. [CrossRef]

37. Hastie, T.; Tibshirani, R.; Friedman, J. The Elements of Statistical Learning: Data Mining, Inference and Prediction, 2nd ed.; Springer: New York, NY, USA, 2009; pp. 389-414. 
38. Alizadeh, Z.; Yazdi, J.; Kim, J.H.; Al-Shamiri, A.K. Assessment of Machine Learning Techniques for Monthly Flow Prediction. Water 2018, 10, 1676. [CrossRef]

39. Sutanudjaja, E.H.; van Beek, L.P.H.; de Jong, S.M.; van Geer, F.C.; Bierkens, M.F.P. Calibrating a large-extent high-resolution coupled groundwater-land surface model using soil moisture and discharge data. Water Resour. Res. 2014, 50, 687-705. [CrossRef]

40. Li, Y.; Grimaldi, S.; Pauwels, V.R.N.; Walker, J.P. Hydrologic model calibration using remotely sensed soil moisture and discharge measurements: The impact on predictions at gauged and ungauged locations. J. Hydrol. 2018, 557, 897-909. [CrossRef]

41. Bai, P.; Liu, X.M.; Liu, C.M. Improving hydrological simulations by incorporating GRACE data for model calibration. J. Hydrol. 2018, 557, 291-304. [CrossRef]

42. Rientjes, T.H.M.; Muthuwatta, L.P.; Bos, M.G.; Booij, M.J.; Bhatti, H.A. Multi-variable calibration of a semi-distributed hydrological model using streamflow data and satellite-based evapotranspiration. J. Hydrol. 2013, 505, 276-290. [CrossRef]

43. Tuo, Y.; Marcolini, G.; Disse, M.; Chiogn, G. A multi-objective approach to improve SWAT model calibration in alpine catchments. J. Hydrol. 2018, 559, 347-360. [CrossRef]

44. Zink, M.; Mai, J.; Cuntz, M.; Samaniego, L. Conditioning a hydrologic model using patterns of remotely sensed land surface temperature. Water Resour. Res. 2018, 54, 2976-2998. [CrossRef]

45. Wanders, N.; Karssenberg, D.; De Roo, A.; De Jong, S.M.; Bierkens, M.F.P. The suitability of remotely sensed soil moisture for improving operational flood forecasting. Hydrol. Earth Syst. Sci. 2014, 18, 2343-2357. [CrossRef]

46. López, P.L.; Wanders, N.; Schellekens, J.; Renzullo, L.; Sutanudjaja, E.; Bierkens, M. Improved large-scale hydrological modelling through the assimilation of streamflow and downscaled satellite soil moisture observations. Hydrol. Earth Syst. Sci. 2016, 20, 3059-3076. [CrossRef]

47. Montero, R.A.; Schwanenberg, D.; Krahe, P.; Lisniak, D.; Sensoy, A.; Sorman, A.A.; Akkol, B. Moving horizon estimation for assimilating H-SAF remote sensing data into the HBV hydrological model. Adv. Water Resour. 2016, 92, 248-257. [CrossRef]

48. Zhang, Y.; Hou, J.L.; Gu, J.; Huang, C.L.; Li, X. SWAT-based hydrological data assimilation system (SWAT-HDAS): Description and case application to river basin-scale hydrological predictions. J. Adv. Model. Earth. Syst. 2017, 9, 2863-2882. [CrossRef]

49. Leach, J.M.; Kornelsen, K.C.; Coulibaly, P. Assimilation of near-real time data products into models of an urban basin. J. Hydrol. 2018, 563, 51-64. [CrossRef]

50. Koster, R.D.; Liu, Q.; Mahanama, S.P.P.; Reichle, R.H. Improved Hydrological Simulation Using SMAP Data: Relative Impacts of Model Calibration and Data Assimilation. J. Hydrometeorol. 2018, 19, 727-741. [CrossRef]

51. Getirana, A.C.V.; Boone, A.; Yamazaki, D.; Decharme, B.; Papa, F.; Mognard, N. The Hydrological Modeling and Analysis Platform (HyMAP): Evaluation in the Amazon Basin. J. Hydrometeorol. 2012, 13, 1641-1665. [CrossRef]

52. Xue, Z.G.; Gochis, D.J.; Yu, W.; Keim, B.D.; Rohli, R.V.; Zang, Z.C.; Sampson, K.; Dugger, A.; Sathiaraj, D.; Ge, Q. Modeling Hydroclimatic Change in Southwest Louisiana Rivers. Water 2018, 10, 596. [CrossRef]

53. Chen, X.; Long, D.; Hong, Y.; Zeng, C.; Yan, D. Improved modeling of snow and glacier melting by a progressive two-stage calibration strategy with GRACE and multisource data: how snow and glacier meltwater contributes to the runoff of the Upper Brahmaputra River basin? Water Resour. Res. 2017, 53, 2431-2466. [CrossRef]

54. Winsemius, H.C. Satellite Data as Complementary Information for Hydrological Modelling. Ph.D. Thesis, Faculty of the Civil Engineering and Geosciences, Delft University of Technology, Delft, The Netherlands, 2009.

55. Sheffield, J.; Wood, E.F.; Pan, M.; Beck, H.; Coccia, G.; Serrat-Capdevila, A.; Verbist, K. Satellite remote sensing for water resources management: potential for supporting sustainable development in data-poor regions. Water Resour. Res. 2018, 54, 9724-9758. [CrossRef]

56. Sang, X.F.; Zhou, Z.H.; Qin, D.Y.; Wei, H.B. Application of improved SWAT model to area with strong human activities. J. Hydraul. Eng. 2008, 39, 1377-1383. (In Chinese)

57. Zhang, Y.Y.; Xia, J.; Chen, J.F.; Zhang, M.H. Water quantity and quality optimization modeling of dams operation based on SWAT in Wenyu River Catchment, China. Environ. Monit. Assess. 2011, 173, 409-430. [CrossRef] 
58. Duan, Q.Y.; Sorooshian, S.; Gupta, V.K. Optimal Use of the SCE-UA Global Optimization Method for Calibrating Watershed Models. J. Hydrol. 1994, 158, 265-284. [CrossRef]

59. Duan, Q.Y.; Sorooshian, S.; Gupta, V. Effective and efficient global optimization for conceptual rainfall-runoff models. Water Resour. Res. 1992, 28, 1015-1031. [CrossRef]

60. Zhang, X.; Srinivasan, R.; Van Liew, M. Multi-site calibration of the SWAT model for hydrologic modeling. Trans. ASABE 2008, 51, 2039-2049. [CrossRef]

61. Minville, M.; Cartier, D.; Guay, C.; Leclaire, L.-A.; Audet, C.; Le Digabel, S.; Merleau, J. Improving process representation in conceptual hydrological model calibration using climate simulations. Water Resour. Res. 2014, 50, 5044-5073. [CrossRef]

62. Nijssen, B.; Lettenmaier, D.P. Effect of precipitation sampling error on simulated hydrological fluxes and states: anticipating the global precipitation measurement satellites. J. Geophys. Res. 2004, 109, D02103. [CrossRef]

63. Yilmaz, K.K.; Hogue, T.S.; Hsu, K.-L.; Sorooshian, S.; Gupta, H.V.; Wagener, T. Intercomparison of rain gauge, radar, and satellite-based precipitation estimates with emphasis on hydrologic forecasting. J. Hydrometeorol. 2005, 6, 497-517. [CrossRef]

64. Heistermann, M.; Kneis, D. Benchmarking quantitative precipitation estimation by conceptual rainfall-runoff modeling. Water Resour. Res. 2011, 47, W06514. [CrossRef]

65. Thiemig, V.; Rojas, R.; Zambrano-Bigiarini, M.; Roo, A.D. Hydrological evaluation of satellite-based rainfall estimates over the Volta and Baro-Akobo Basin. J. Hydrol. 2013, 499, 324-338. [CrossRef]

66. Falck, A.S.; Maggioni, V.; Tomasella, J.; Vila, D.A.; Diniz, F.L.R. Propagation of satellite precipitation uncertainties through a distributed hydrologic model: A case study in the Tocantins-Araguaia basin in Brazil. J. Hydrol. 2015, 527, 943-957. [CrossRef]

67. Tang, G.; Zeng, Z.Y.; Long, D.; Guo, X.L. Statistical and hydrological comparisons between TRMM and GPM Level-3 products over a midlatitude basin: Is Day-1 IMERG a Good Successor for TMPA 3B42V7? J. Hydrometeorol. 2016, 17, 121-137. [CrossRef]

68. Li, D.; Christakos, G.; Ding, X.X.; Wu, J.P. Adequacy of TRMM satellite rainfall data in driving the SWAT modeling of Tiaoxi catchment (Taihu lake basin, China). J. Hydrol. 2018, 556, 1139-1152. [CrossRef]

69. Zhu, H.L.; Li, Y.; Huang, Y.W.; Li, Y.C.; Hou, C.C.; Shi, X.L. Evaluation and hydrological application of satellite-based precipitation datasets in driving hydrological models over the Huifa river basin in Northeast China. Atmos. Res. 2018, 207, 28-41. [CrossRef]

70. Qi, W.; Liu, J.G.; Yang, H.; Sweetapple, C. An ensemble-based dynamic Bayesian averaging approach for discharge simulations using multiple global precipitation products and hydrological models. J. Hydrol. 2018, 558, 405-420. [CrossRef]

71. Worqlul, A.W.; Ayana, E.K.; Maathuis, B.H.P.; MacAlister, C.; Philpot, W.D.; Osorio Leyton, J.M.; Steenhuis, T.S. Performance of bias corrected MPEG rainfall estimate for rainfall-runoff simulation in the upper Blue Nile Basin, Ethiopia. J. Hydrol. 2018, 556, 1182-1191. [CrossRef]

72. Yuan, F.; Wang, B.; Shi, C.X.; Cui, W.; Zhao, C.X.; Liu, Y.; Ren, L.L.; Zhang, L.M.; Zhu, Y.H.; Chen, T.; et al. Evaluation of hydrological utility of IMERG Final run V05 and TMPA 3B42V7 satellite precipitation products in the Yellow River source region, China. J. Hydrol. 2018, 567, 696-711. [CrossRef]

73. Jiang, L.G.; Bauer-Gottwein, P. How do GPM IMERG precipitation estimates perform as hydrological model forcing? Evaluation for 300 catchments across Mainland China. J. Hydrol. 2019, 572, 486-500. [CrossRef]

74. Deng, P.X.; Zhang, M.Y.; Bing, J.P.; Jia, J.W.; Zhang, D.D. Evaluation of the GSMaP_Gauge products using rain gauge observations and SWAT model in the Upper Hanjiang River Basin. Atmos. Res. 2019, 219, 153-165. [CrossRef]

75. Falck, A.S.; Maggioni, V.; Tomasella, J.; Diniz, F.L.R.; Mei, Y.; Beneti, C.A.; Herdies, D.L.; Neundorf, R.; Caram, R.O.; Rodriguez, D.A. Improving the use of ground-based radar rainfall data for monitoring and predicting floods in the Iguaçu river basin. J. Hydrol. 2018, 567, 626-636. [CrossRef]

76. Skinner, C.J.; Bellerby, T.J.; Greatrex, H.; Grimes, D.I.F. Hydrological modelling using ensemble satellite rainfall estimates in a sparsely gauged river basin: The need for whole-ensemble calibration. J. Hydrol. 2015, 522, 110-122. [CrossRef]

77. Sun, R.C.; Yuan, H.L.; Liu, X.L.; Jiang, X.M. Evaluation of the latest satellite-gauge precipitation products and their hydrologic applications over the Huaihe River basin. J. Hydrol. 536, 302-319. [CrossRef] 
78. Zambrano-Bigiarini, M.; Nauditt, A.; Birkel, C.; Verbist, K.; Ribbe, L. Temporal and spatial evaluation of satellite-based rainfall estimates across the complex topographical and climatic gradients of Chile. Hydrol. Earth Syst. Sci. 2017, 21, 1295-1320. [CrossRef]

79. Maggioni, V.; Massari, C. On the performance of satellite precipitation products in riverine flood modeling: A review. J. Hydrol. 2018, 558, 214-224. [CrossRef]

80. Shen, Y.; Xiong, A.Y.; Wang, Y.; Xie, P.P. Performance of high-resolution satellite precipitation products over China. J. Geophys. Res. 2010, 115, D02114. [CrossRef]

81. Woldemeskel, F.M.; Sivakumar, B.; Sharma, A. Merging gauge and satellite rainfall with specification of associated uncertainty across Australia. J. Hydrol. 2013, 499, 167-176. [CrossRef]

82. Lai, C.G.; Zhong, R.D.; Wang, Z.L.; Wu, X.Q.; Chen, X.H.; Wang, P.; Lian, Y.Q. Monitoring hydrological drought using long-term satellite-based precipitation data. Sci. Total Environ. 2019, 649, 1198-1208. [CrossRef]

83. Huffman, G.J.; Bolvin, D.T.; Nelkin, E.J.; Wolff, D.B.; Adler, R.F.; Gu, G.; Hong, Y.; Bowman, K.P.; Stocker, E.F. The TRMM Multisatellite Precipitation Analysis (TMPA): Quasi-Global, Multiyear, Combined-Sensor Precipitation Estimates at Fine Scales. J. Hydrometeorol. 2007, 8, 38-55. [CrossRef]

84. Hou, A.Y.; Kakar, R.K.; Neeck, S.; Azarbarzin, A.A.; Kummerow, C.D.; Kojima, M.; Oki, R.; Nakamura, K.; Iguchi, T. The global precipitation measurement mission. Bull. Am. Meteorol. Soc. 2014, 95, 701-722. [CrossRef]

85. Joyce, R.J.; Janowiak, J.E.; Arkin, P.A.; Xie, P.P. CMORPH: A method that produces global precipitation estimates from passive microwave and infrared data at high spatial and temporal resolution. J. Hydrometeorol. 2004, 5, 87-503. [CrossRef]

86. Sorooshian, S.; Hsu, K.L.; Gao, X.G.; Gupta, H.V.; Imam, B.; Braithwaite, D. Evaluation of PERSIANN system satellite-based estimates of tropical rainfall. Bull. Am. Meteorol. Soc. 2000, 81, 2035-2046. [CrossRef]

87. Kubota, T.; Shige, S.; Hashizume, H.; Aonashi, K.; Takahashi, N.; Seto, S.; Hirose, M.; Takayabu, Y.N.; Ushio, T.; Nakagawa, K.; et al. Global precipitation map using satellite-borne microwave radiometers by the GSMaP project: production and validation. IEEE Trans. Geosci. Remote Sens. 2007, 45, 2259-2275. [CrossRef]

88. Turk, F.J.; Miller, S.D. Toward improved characterization of remotely sensed precipitation regimes with MODIS/AMSR-E blended data techniques. IEEE. Trans. Geosci. Remote. Sens. 2005, 43, 1059-1069. [CrossRef]

89. Stisen, S.; Sandholt, I. Evaluation of remote-sensing-based rainfall products through predictive capability in hydrological runoff modeling. Hydrol. Process. 2010, 24, 879-891. [CrossRef]

90. Yong, B.; Ren, L.L.; Hong, Y.; Wang, J.H.; Gourley, J.J.; Jiang, S.H.; Chen, X.; Wang, W. Hydrologic evaluation of multisatellite precipitation analysis standard precipitation products in basins beyond its inclined latitude band: A case study in Laohahe basin, China. Water Resour. Res. 2010, 46, W07542. [CrossRef]

91. Bitew, M.M.; Gebremichael, M. Evaluation of satellite rainfall products through hydrologic simulation in a fully distributed hydrologic model. Water Resour. Res. 2011, 47, W06526. [CrossRef]

92. Xue, X.; Hong, Y.; Limaye, A.S.; Gourley, J.J.; Huffman, G.J.; Khan, S.I.; Dorji, C.; Chen, S. Statistical and hydrological evaluation of TRMM-based Multi-Satellite Precipitation Analysis over the Wangchu basin of Bhutan: Are the latest satellite precipitation products 3B42V7 ready for use in ungauged basins? J. Hydrol. 2013, 499, 91-99. [CrossRef]

93. Meng, J.; Li, L.; Hao, Z.C.; Wang, J.H.; Shao, Q.X. Suitability of TRMM satellite rainfall in driving a distributed hydrological model in the source region of Yellow River. J. Hydrol. 2014, 509, 320-332. [CrossRef]

94. Ashouri, H.; Nguyen, P.; Thorstensen, A.; Hsu, K.; Sorooshian, S.; Braithwaite, D. Assessing the Efficacy of High-Resolution Satellite-Based PERSIANN-CDR Precipitation Product in Simulating Streamflow. J. Hydrometeorol. 2016, 17, 2061-2076. [CrossRef]

95. Zubieta, R.; Getirana, A.; Espinoza, J.C.; Lavado-Casimiro, W.; Aragon, L. Hydrological modeling of the Peruvian-Ecuadorian Amazon Basin using GPM-IMERG satellite-based precipitation dataset. Hydrol. Earth Syst. Sci. 2017, 21, 3543-3555. [CrossRef]

96. Wang, Z.L.; Zhong, R.D.; Lai, C.G.; Chen, J.C. Evaluation of the GPM IMERG satellite-based precipitation products and the hydrological utility. Atmos. Res. 2017, 196, 151-163. [CrossRef]

97. Su, F.; Hong, Y.; Lettenmaier, D.P. Evaluation of TRMM multisatellite precipitation analysis (TMPA) and its utility in hydrologic prediction in the La Plata Basin. J. Hydrometeorol. 2008, 9, 622-640. [CrossRef]

98. Maggioni, V.; Meyers, P.C.; Robinson, M.D. A Review of Merged High-Resolution Satellite Precipitation Product Accuracy during the Tropical Rainfall Measuring Mission (TRMM) Era. J. Hydrometeorol. 2016, 17, 1101-1117. [CrossRef] 
99. Beck, H.E.; Vergopolan, N.; Pan, M.; Levizzani, V.; van Dijk, A.I.J.M.; Weedon, G.P.; Brocca, L.; Pappenberger, F.; Huffman, G.J.; Wood, E.F. Global-scale evaluation of 22 precipitation datasets using gauge observations and hydrological modeling. Hydrol. Earth Syst. Sci. 2017, 21, 6201-6217. [CrossRef]

100. Gao, Z.; Long, D.; Tang, G.Q.; Zeng, C.; Huang, J.S.; Hong, Y. Assessing the potential of satellite-based precipitation estimates for flood frequency analysis in ungauged or poorly gauged tributaries of China's Yangtze River basin. J. Hydrol. 2017, 550, 478-496. [CrossRef]

101. Kneis, D.; Chatterjee, C.; Singh, R. Evaluation of TRMM rainfall estimates over a large Indian river basin (Mahanadi). Hydrol. Earth Syst. Sci. 2014, 18, 2493-2502. [CrossRef]

102. Su, J.B.; Lü, H.S.; Zhu, Y.H.; Cui, Y.F.; Wang, X.Y. Evaluating the hydrological utility of latest IMERG products over the Upper Huaihe River Basin, China. Atmos. Res. 2019, 225, 17-29. [CrossRef]

103. Li, N.; Tang, G.Q.; Zhao, P.; Hong, Y.; Gou, Y.B.; Yang, K. Statistical assessment and hydrological utility of the latest multi-satellite precipitation analysis IMERG in Ganjiang River basin. Atmos. Res. 2017, 183, $212-223$. [CrossRef]

104. Jiang, S.H.; Ren, L.L.; Xu, C.Y.; Yong, B.; Yuan, F.; Liu, Y.; Yang, X.L.; Zeng, X.M. Statistical and hydrological evaluation of the latest Integrated Multi-satellitE Retrievals for GPM (IMERG) over a midlatitude humid basin in South China. Atmos. Res. 2018, 214, 418-429. [CrossRef]

105. Tuo, Y.; Duan, Z.; Disse, M.; Chiogna, G. Evaluation of precipitation input for SWAT modeling in Alpine catchment: A case study in the Adige river basin (Italy). Sci. Total Environ. 2016, 573, 66-82. [CrossRef]

106. Camici, S.; Ciabatta, L.; Massari, C.; Brocca, L. How reliable are satellite precipitation estimates for driving hydrological models: A verification study over the Mediterranean area. J. Hydrol. 2018, 563, 950-961. [CrossRef]

107. Jung, M.; Reichstein, M.; Ciais, P.; Seneviratne, S.I.; Sheffield, J.; Goulden, M.L.; Bonan, G.; Cescatti, A.; Chen, J.; de Jeu, R. Recent decline in the global land evapotranspiration trend due to limited moisture supply. Nature 2010, 467, 951-954. [CrossRef]

108. Zou, L.; Zhan, C.S.; Xia, J.; Wang, T.J.; Gippel, C.J. Implementation of evapotranspiration data assimilation with catchment scale distributed hydrological model via an ensemble Kalman Filter. J. Hydrol. 2017, 549, 685-702. [CrossRef]

109. Yin, J.; Zhan, C.S.; Ye, W. An experimental study on evapotranspiration data assimilation based on the hydrological model. Water Resour. Manag. 2016, 30, 5263-5279. [CrossRef]

110. Dong, Q.Q.; Zhan, C.S.; Wang, H.X.; Wang, F.Y.; Zhu, M.C. A review on evapotranspiration data assimilation based on hydrological models. J. Geogr. Sci. 2016, 26, 230-242. [CrossRef]

111. Andersen, J.; Dybkjaer, G.; Jensen, K.H.; Refsgaard, J.C.; Rasmussen, K. Use of remotely sensed precipitation and leaf area index in a distributed hydrological model. J. Hydrol. 2002, 264, 34-50. [CrossRef]

112. Xu, C.Y.; Singh, V.P. Review on regional water resources assessment models under stationary and changing climate. Water Resour. Manag. 2004, 18, 591-612. [CrossRef]

113. Zhang, K.; Kimball, J.S.; Running, S.W. A review of remote sensing based actual evapotranspiration estimation. WIREs Water 2016, 3, 834-853. [CrossRef]

114. Pan, M.; Wood, E.F.; Wojcik, R.; McCabe, M.F. Estimation of regional terrestrial water cycle using multi-sensor remote sensing observations and data assimilation. Remote Sens. Environ. 2008, 112, 1282-1294. [CrossRef]

115. Qin, C.B.; Jia, Y.W.; Su, Z.; Zhou, Z.H.; Qiu, Y.Q.; Shen, S.H. Integrating remote sensing information into a distributed hydrological model for improving water budget predictions in large-scale basins through data assimilation. Sensors 2008, 8, 4441-4465. [CrossRef]

116. Mu, Q.Z.; Zhao, M.S.; Running, S.W. Improvements to a MODIS global terrestrial evapotranspiration algorithm. Remote Sens. Environ. 2011, 115, 1781-1800. [CrossRef]

117. Herman, M.R.; Nejadhashemi, A.P.; Abouali, M.; Hernandez-Suarez, J.S.; Daneshvar, F.; Zhang, Z.; Anderson, M.C.; Sadeghi, A.M.; Hain, C.R.; Sharifi, A. Evaluating the role of evapotranspiration remote sensing data in improving hydrological modeling predictability. J. Hydrol. 2018, 556, 39-49. [CrossRef]

118. Wooldridge, S.A.; Kalma, J.D.; Walker, J.P. Importance of soil moisture measurements for inferring parameters in hydrologic models of low-yielding ephemeral catchments. Environ. Model. Softw. 2003, 18, 35-48. [CrossRef]

119. Trudel, M.; Leconte, R.; Paniconi, C. Analysis of the hydrological response of a distributed physically-based model using post-assimilation (EnKF) diagnostics of streamflow and in situ soil moisture observations. J. Hydrol. 2014, 514, 192-201. [CrossRef] 
120. Yan, H.; Moradkhani, H. Combined assimilation of streamflow and satellite soil moisture with the particle filter and geostatistical modeling. Adv. Water Resour. 2016, 94, 364-378. [CrossRef]

121. Sun, L.Q.; Seidou, O.; Nistor, I.; Goïta, K.; Magagi, R. Simultaneous assimilation of in situ soil moisture and streamflow in the SWAT model using the Extended Kalman Filter. J. Hydrol. 2016, 543, 671-685. [CrossRef]

122. Kumar, S.V.; Dirmeyer, P.A.; Peters-Lidard, C.D.; Bindlish, R.; Bolten, J. Information theoretic evaluation of satellite soil moisture retrievals. Remote Sens. Environ. 2018, 204, 392-400. [CrossRef]

123. Han, E.J.; Merwade, V.; Heathman, G.C. Implementation of surface soil moisture data assimilation with watershed scale distributed hydrological model. J. Hydrol. 2012, 416-417, 98-117. [CrossRef]

124. Patil, A.; Ramsankaran, R. Improved streamflow simulations by coupling soil moisture analytical relationship in EnKF based hydrological data assimilation framework. Adv. Water Resour. 2018, 121, 173-188. [CrossRef]

125. Meng, S.S.; Xie, X.H.; Liang, S.L. Assimilation of soil moisture and streamflow observations to improve flood forecasting with considering runoff routing lags. J. Hydrol. 2017, 550, 568-579. [CrossRef]

126. Matgen, P.; Fenicia, F.; Heitz, S.; Plaza, D.; de Keyser, R.; Pauwels, V.R.N.; Wagner, W.; Savenije, H. Can ASCAT-derived soil wetness indices reduce predictive uncertainty in well-gauged areas? A comparison with in situ observed soil moisture in an assimilation application. Adv. Water Resour. 2012, 44, 49-65. [CrossRef]

127. Lei, F.N.; Huang, C.L.; Shen, H.F.; Li, X. Improving the estimation of hydrological states in the SWAT model via the ensemble Kalman smoother: Synthetic experiments for the Heihe River Basin in northwest China. Adv. Water Resour. 2014, 67, 32-45. [CrossRef]

128. Francois, C.; Quesney, A.; Ottle, C. Sequential assimilation of ERS-1 SAR data into a coupled land surface hydrological model using an extended Kalman filter. J. Hydrometeorol. 2003, 4, 473-487. [CrossRef]

129. Lakshmi, V. The role of satellite remote sensing in the Prediction of Ungauged Basins. Hydrol. Process. 2004, 18, 1029-1034. [CrossRef]

130. Kornelsen, K.C.; Coulibaly, P. Advances in soil moisture retrieval from synthetic aperture radar and hydrological applications. J. Hydrol. 2013, 476, 460-489. [CrossRef]

131. Alvarez-Garreton, C.; Ryu, D.; Western, A.W.; Su, C.H.; Crow, W.T.; Robertson, D.E.; Leahy, C. Improving operational flood ensemble prediction by the assimilation of satellite soil moisture: Comparison between lumped and semi-distributed schemes. Hydrol. Earth Syst. Sci. 2015, 19, 1659-1676. [CrossRef]

132. Zeng, J.Y.; Li, Z.; Chen, Q.; Bi, H.Y.; Qiu, J.X.; Zou, P.F. Evaluation of remotely sensed and reanalysis soil moisture products over the Tibetan Plateau using in-situ observations. Remote Sens. Environ. 2015, 163, 91-110. [CrossRef]

133. Alexandridis, T.K.; Cherif, I.; Bilas, G.; Almeida, W.G.; Hartanto, I.M.; van Andel, S.J.; Araújo, A. Spatial and Temporal Distribution of Soil Moisture at the Catchment Scale Using Remotely-Sensed Energy Fluxes. Water 2016, 8, 32. [CrossRef]

134. Brocca, L.; Melone, F.; Moramarco, T.; Wagner, W.; Naeimi, V.; Bartalis, Z.; Hasenauer, S. Improving runoff prediction through the assimilation of the ASCAT soil moisture product. Hydrol. Earth Syst. Sci. 2010, 14, 1881-1893. [CrossRef]

135. Wanders, N.; Karssenberg, D.; Bierkens, M.; Bierkens, M.; Parinussa, R.; de Jeu, R.; van Dam, J.; de Jong, S. Observation uncertainty of satellite soil moisture products determined with physically-based modeling. Remote Sens. Environ. 2012, 127, 341-356. [CrossRef]

136. Brocca, L.; Hasenauer, S.; Lacava, T.; Melone, F.; Moramarco, T.; Wagner, W.; Dorigo, W.; Matgen, P.; Martínez-Fernández, J.; Llorens, P.; et al. Soil moisture estimation through ASCAT and AMSR-E sensors: An intercomparison and validation study across Europe. Remote Sens. Environ. 2011, 115, 3390-3408. [CrossRef]

137. Liu, Y.Y.; Dorigo, W.A.; Parinussa, R.M.; de Jeu, R.A.M.; Wagner, W.; McCabe, M.F.; Evans, J.P.; van Dijk, A.I.J.M. Trend-preserving blending of passive and active microwave soil moisture retrievals. Remote Sens. Environ. 2012, 123, 280-297. [CrossRef]

138. Taylor, C.M.; de Jeu, R.A.; Guichard, F.; Harris, P.P.; Dorigo, W.A. Afternoon rain more likely over drier soils. Nature 2012, 489, 423-426. [CrossRef]

139. Brocca, L.; Moramarco, T.; Melone, F.; Wagner, W.; Hasenauer, S.; Hahn, S. Assimilation of surface- and root-zone ASCAT soil moisture products into rainfall- runoff modeling. IEEE Trans. Geosci. Remote Sens. 2012, 50, 2542-2555. [CrossRef]

140. Wagner, W.; Lemoine, G.; Rott, H. A method for estimating soil moisture from ERS scatterometer and soil data. Remote Sens. Environ. 1999, 70, 191-207. [CrossRef] 
141. Brocca, L.; Moramarco, T.; Dorigo, W.; Wagner, W. Assimilation of satellite soil moisture data into rainfall-runoff modelling for several catchments worldwide. In Proceedings of the 2013 IEEE Geoscience and Remote Sensing Symposium, Melbourne, Australia, 21-26 July 2013; pp. 2281-2284.

142. Maxwell, D.H.; Jackson, B.M.; McGregor, J. Constraining the ensemble Kalman filter for improved streamflow Forecasting. J. Hydrol. 2018, 560, 127-140. [CrossRef]

143. Crow, W.T.; Van Loon, E. Impact of incorrect model error assumptions on the sequential assimilation of remotely sensed surface soil moisture. J. Hydrometeorol. 2006, 7, 421-432. [CrossRef]

144. Pauwels, V.R.N.; Hoeben, R.; Verhoest, N.E.C.; De Troch, F.P. The importance of the spatial patterns of remotely sensed soil moisture in the improvement of discharge predictions for small-scale basins through data assimilation. J. Hydrol. 2001, 251, 88-102. [CrossRef]

145. Crow, W.T.; Ryu, D. A new data assimilation approach for improving runoff prediction using remotely-sensed soil moisture retrievals. Hydrol. Earth Syst. Sci. 2009, 13, 1-16. [CrossRef]

146. Zhang, Y.; Hou, J.; Cao, Y.; Gu, J.; Huang, C. OpenMP parallelization of a gridded SWAT (SWATG). Comput. Geosci. 109, 228-237. [CrossRef]

147. Andreadis, K.M.; Lettenmaier, D.P. Assimilating remotely sensed snow observations into a macroscale hydrology model. Adv. Water Resour. 2006, 29, 872-886. [CrossRef]

148. Franz, K.J.; Hogue, T.S.; Barik, M.; He, M. Assessment of SWE data assimilation for ensemble streamflow predictions. J. Hydrol. 2014, 519, 2737-2746. [CrossRef]

149. Griessinger, N.; Seibert, J.; Magnusson, J.; Jonas, T. Assessing the benefit of snow data assimilation for runoff modeling in Alpine catchments. Hydrol. Earth Syst. Sci. 2016, 20, 3895-3905. [CrossRef]

150. Moradkhani, H. Hydrologic remote sensing and land surface data assimilation. Sensors 2008, 8, $2986-3004$. [CrossRef]

151. DeChant, C.M.; Moradkhani, H. Improving the characterization of initial condition for ensemble streamflow prediction using data assimilation. Hydrol. Earth Syst. Sci. 2011, 15, 3399-3410. [CrossRef]

152. Jörg-Hess, S.; Griessinger, N.; Zappa, M. Probabilistic Forecasts of Snow Water Equivalent and Runoff in Mountainous Areas. J. Hydrometeorol. 2015, 16, 2169-2186. [CrossRef]

153. Bergeron, J.M.; Trudel, M.; Leconte, R. Combined assimilation of streamflow and snow water equivalent for mid-term ensemble streamflow forecasts in snow-dominated regions. Hydrol. Earth Syst. Sci. 2016, 20, 4375-4389. [CrossRef]

154. Huang, C.; Newman, A.J.; Clark, M.P.; Wood, A.W.; Zheng, X. Evaluation of snow data assimilation using the ensemble Kalman filter for seasonal streamflow prediction in the western United States. Hydrol. Earth Syst. Sci. 2017, 21, 635-650. [CrossRef]

155. Liu, Y.Q.; Peters-Lidard, C.D.; Kumar, S.V.; Arsenault, K.R.; Mocko, D.M. Blending satellite-based snow depth products with in situ observations for streamflow predictions in the Upper Colorado River Basin. Water Resour. Res. 2015, 51, 1182-1202. [CrossRef]

156. Magand, C.; Ducharne, A.; Le Moine, N.; Gascoin, S. Introducing hysteresis in snow depletion curves to improve the water budget of a land surface model in an Alpine catchment. J. Hydrometeorol. 2014, 15, 631-649. [CrossRef]

157. Dietz, A.J.; Kuenzer, C.; Gessner, U.; Dech, S. Remote sensing of snow-A review of available methods. Int. J. Remote Sens. 2012, 33, 4094-4134. [CrossRef]

158. Hall, D.; Riggs, G.; Valomonson, V.; DiGirolamo, N.; Bayr, K. MODIS snow-cover products. Remote Sens. Environ. 2002, 83, 181-194. [CrossRef]

159. Kumar, S.V.; Peters-Lidard, C.D.; Arsenault, K.R.; Getirana, A.; Mocko, D.; Liu, Y.Q. Quantifying the added value of snow cover area observations in passive microwave snow depth data assimilation. J. Hydrometeorol. 2015, 16, 1736-1741. [CrossRef]

160. Wang, L.; Derksen, C.; Brown, R. Detection of pan-Arctic terrestrial snowmelt from QuickSCAT, $2000-2005$. Remote Sens. Environ. 2008, 112, 3794-3805. [CrossRef]

161. Kumar, S.V.; Peters-Lidard, C.D.; Mocko, D.; Reichle, R.; Liu, Y.Q.; Arsenault, K.R.; Xia, Y.L.; Ek, M.; Riggs, G.; Livneh, B.; et al. Assimilation of remotely sensed soil moisture and snow depth retrievals for drought estimation. J. Hydrometeorol. 2014, 15, 2446-2469. [CrossRef]

162. Dong, J.; Walker, J.; Houser, P. Factors affecting remotely sensed snow water equivalent uncertainty. Remote Sens. Environ. 2005, 97, 68-82. [CrossRef] 
163. Liu, Y.Q.; Peters-Lidard, C.; Kumar, S.; Foster, J.; Shaw, M.; Tian, Y.; Fall, G. Assimilating satellite-based snow depth and snow cover products for improving snow predictions in Alaska. Adv. Water Resour. 2013, 54, 208-227. [CrossRef]

164. Forman, B.A.; Reichle, R.H.; Rodell, M. Assimilation of terrestrial water storage from GRACE in a snow-dominated basin. Water Resour. Res. 2012, 48, W01507. [CrossRef]

165. Tian, S.; Tregoning, P.; Renzullo, L.J.; van Dijk, A.I.J.M.; Walker, J.P.; Pauwels, V.R.N.; Allgeyer, S. Improved water balance component estimates through joint assimilation of GRACE water storage and SMOS soil moisture retrievals. Water Resour. Res. 2017, 53, 1820-1840. [CrossRef]

166. Schumacher, M.; Forootan, E.; van Dijk, A.I.J.M.; Müller Schmied, H.; Crosbie, R.S.; Kusche, J.; Döll, P. Improving drought simulations within the Murray-Darling Basin by combined calibration/assimilation of GRACE data into the WaterGAP Global Hydrology Model. Remote Sens. Environ. 2018, 204, 212-228. [CrossRef]

167. Tangdamrongsub, N.; Steele-Dunne, S.C.; Gunter, B.C.; Ditmar, P.G.; Sutanudjaja, E.H.; Xie, T.; Wang, Z. Improving estimates of water resources in a semi-arid region by assimilating GRACE data into the PCR-GLOBWB hydrological model. Hydrol. Earth Syst. Sci. 2017, 21, 2053-2074. [CrossRef]

168. Tangdamrongsub, N.; Steele-Dunne, S.C.; Gunter, B.C.; Ditmar, P.G.; Weerts, A.H. Data assimilation of GRACE terrestrial water storage estimates into a regional hydrological model of the Rhine River basin. Hydrol. Earth Syst. Sci. 2015, 19, 2079-2100. [CrossRef]

169. Corbari, C.; Mancini, M.; Li, J.; Su, Z. Can satellite land surface temperature data be used similarly to river discharge measurements for distributed hydrological model calibration? Hydrol. Sci. J. 2015, 60, $202-217$. [CrossRef]

170. Corbari, C.; Mancini, M. Calibration and validation of a distributed energy-water balance model using satellite data of land surface temperature and ground discharge measurements. J. Hydrometeorol. 2014, 15, 376-392. [CrossRef]

171. Silvestro, F.; Gabellani, S.; Rudari, R.; Delogu, F.; Laiolo, P.; Boni, G. Uncertainty reduction and parameter estimation of a distributed hydrological model with ground and remote-sensing data. Hydrol. Earth Syst. Sci. 2015, 19, 1727-1751. [CrossRef]

172. Sun, W.; Ishidaira, H.; Bastola, S.; Yu, J. Estimating daily time series of streamflow using hydrological model calibrated based on satellite observations of river water surface width: Toward real world applications. Environ. Res. 2015, 139, 36-45. [CrossRef]

173. Sichangi, A.W.; Wang, L.; Hu, Z.D. Estimation of river discharge solely from remote-sensing derived Data: An initial study over the Yangtze River. Remote Sens. 2018, 10, 1385. [CrossRef]

174. Gleason, C.J.; Smith, L.C. Toward global mapping of river discharge using satellite images and at-many-stations hydraulic geometry. Proc. Natl. Acad. Sci. USA 2014, 111, 4788-4791. [CrossRef]

175. Gleason, C.J.; Smith, L.C.; Lee, J. Retrieval of river discharge solely from satellite imagery and at-many-stations hydraulic geometry: Sensitivity to river form and optimization parameters. Water Resour. Res. 2014, 50, 9604-9619. [CrossRef]

176. Sun, W.C.; Fan, J.; Wang, G.Q.; Ishidaira, H.; Bastola, S.; Yu, J.S.; Fu, Y.H.; Kiem, A.S.; Zuo, D.P.; Xu, Z.X. Calibrating a hydrological model in a regional river of the Qinghai-Tibet plateau using river water width determined from high spatial resolution satellite images. Remote Sens. Environ. 2018, 214, 100-114. [CrossRef]

177. Alsdorf, D.E.; Rodríguez, E.; Lettenmaier, D.P. Measuring surface water from space. Rev. Geophys. 2007, 45, RG2002. [CrossRef]

178. Revilla-Romero, B.; Beck, H.E.; Burek, P.; Salamon, P.; de Roo, A.; Thielen, J. Filling the gaps: Calibrating a rainfall-runoff model using satellite-derived surface water extent. Remote Sens. Environ. 2015, 171, 118-131. [CrossRef]

179. Abbaszadeh, P.; Moradkhani, H.; Yan, H.X. Enhancing hydrologic data assimilation by evolutionary Particle Filter and Markov Chain Monte Carlo. Adv. Water Resour. 2018, 111, 192-204. [CrossRef]

180. Liu, Y.; Weerts, A.H.; Clark, M.P.; Hendricks Franssen, H.-J.; Kumar, S.; Moradkhani, H.; Seo, D.-J.; Schwanenberg, D.; Smith, P.; van Dijk, A.I.J.M.; et al. Advancing data assimilation in operational hydrologic forecasting: progresses, challenges, and emerging opportunities. Hydrol. Earth Syst. Sci. Discuss. 2012, 9, 3415-3472. [CrossRef]

181. Reichle, R.H.; Crow, W.T.; Koster, R.D.; Sharif, H.O.; Mahanama, S.P.P. Contribution of soil moisture retrievals to land data assimilation products. Geophys. Res. Lett. 2008, 35, L01404. [CrossRef] 
182. Parada, L.M.; Liang, X. Impacts of spatial resolutions and data quality on soil moisture data assimilation. J. Geophys. Res. Atmos. 2008, 113, D10101. [CrossRef]

183. Pan, M.; Wood, E.F. Impact of accuracy, spatial availability, and revisit time of satellite-derived surface soil moisture in a multiscale ensemble data assimilation system. IEEE J. Sel. Top. Appl. Earth Obs. Remote Sens. 2010, 3, 49-56. [CrossRef]

184. Entekhabi, D.; Nakamura, H.; Njoku, E.G. Solving the inverse problem for soil moisture and temperature profiles by sequential assimilation of multifrequency remotely sensed observations. IEEE Trans. Geosci. Remote Sens. 1994, 32, 438-448. [CrossRef]

185. Reichle, R.H.; McLaughlin, D.; Entekhabi, D. Hydrologic data assimilation with the ensemble Kalman filter. Mon. Weather Rev. 2002, 130, 103-114. [CrossRef]

186. Margulis, S.A.; McLaughlin, D.; Entekhabi, D.; Dunne, S. Land data assimilation and estimation of soil moisture using measurements from the Southern Great Plains 1997 field experiment. Water Resour. Res. 2002, 38, 1-18. [CrossRef]

187. Clark, M.P.; Rupp, D.E.; Woods, R.A.; Zheng, X.; Ibbitt, R.P.; Slater, A.G.; Schmidt, J.; Uddstrom, M.J. Hydrological data assimilation with the ensemble Kalman filter: Use of streamflow observations to update states in a distributed hydrological model. Adv. Water Resour. 2008, 31, 1309-1324. [CrossRef]

188. Xie, X.; Zhang, D. Data assimilation for distributed hydrological catchment modeling via ensemble Kalman filter. Adv. Water Resour. 2010, 33, 678-690. [CrossRef]

189. Lee, H.; Seo, D.-J.; Koren, V. Assimilation of streamflow and in situ soil moisture data into operational distributed hydrologic models: effects of uncertainties in the data and initial model soil moisture states. Adv. Water Resour. 2011, 34, 1597-1615. [CrossRef]

190. Liu, Y.Q.; Gupta, H.V. Uncertainty in hydrologic modeling: toward an integrated data assimilation framework. Water Resour. Res. 2007, 43, W07401. [CrossRef]

191. Fan, Y.R.; Huang, G.H.; Baetz, B.W.; Li, Y.P.; Huang, K.; Chen, X.; Gao, M. Development of integrated approaches for hydrological data assimilation through combination of ensemble Kalman filter and particle filter methods. J. Hydrol. 2017, 550, 412-426. [CrossRef]

192. De Lannoy, G.J.M.; Reichle, R.H.; Houser, P.R.; Pauwels, V.R.N.; Verhoest, N.E.C. Correcting for forecast bias in soil moisture assimilation with the ensemble Kalman filter. Water Resour. Res. 2007, 43, W09410. [CrossRef]

193. Pathiraja, S.; Marshall, L.; Sharma, A.; Moradkhani, H. Detecting non-stationary hydrologic model parameters in a paired catchment system using data assimilation. Adv. Water Resour. 2016, 94, 103-119. [CrossRef]

194. Pathiraja, S.; Marshall, L.; Sharma, A.; Moradkhani, H. Hydrologic modeling in dynamic catchments: A data assimilation approach. Water Resour. Res. 2016, 52, 3350-3372. [CrossRef]

195. Matgen, P.; Montanari, M.; Hostache, R.; Pfister, L.; Hoffmann, L.; Plaza, D.; Pauwels, V.R.N.; De Lannoy, G.J.M.; De Keyser, R.; Savenije, H. Towards the sequential assimilation of SAR-derived water stages into hydraulic models using the particle filter: Proof of concept. Hydrol. Earth Syst. Sci. 2010, 14, 1773-1785. [CrossRef]

196. DeChant, C.M.; Moradkhani, H. Examining the effectiveness and robustness of sequential data assimilation methods for quantification of uncertainty in hydrologic forecasting. Water Resour. Res. 2012, 48, 1-15. [CrossRef]

197. Moradkhani, H.; Hsu, K.; Gupta, H.; Sorooshian, S. Uncertainty assessment of hydrologic model states and parameters: Sequential data assimilation using particle filter. Water Resour. Res. 2005, 41, W05012. [CrossRef]

198. Moradkhani, H.; Dechant, C.M.; Sorooshian, S. Evolution of ensemble data assimilation for uncertainty quantification using the particle filter-Markov chain Monte Carlo method. Water Resour. Res. 2012, 48, W12520. [CrossRef]

199. Xie, X.H.; Zhang, D.X. A partitioned update scheme for state-parameter estimation of distributed hydrologic models based on the ensemble Kalman filter. Water Resour. Res. 2013, 49, 7350-7365. [CrossRef]

200. Andrieu, C.; Doucet, A.; Holenstein, R. Particle Markov chain Monte Carlo methods. J. R. Stat. Soc. Ser. B. Stat. Methodol. 2010, 72, 269-342. [CrossRef]

201. Lee, H.; Seo, D.-J.; Noh, S.J. A weakly-constrained data assimilation approach to address rainfall-runoff model structural inadequacy in streamflow prediction. J. Hydrol. 2016, 542, 373-391. [CrossRef]

202. Khaki, M.; Ait-El-Fquih, B.; Hoteit, I.; Forootan, E.; Awange, J.; Kuhn, M. A two-update ensemble Kalman filter for land hydrological data assimilation with an uncertain constraint. J. Hydrol. 2017, 555, 447-462. [CrossRef] 
203. Lorenzo, E.D.; Moore, A.M.; Arango, H.G.; Cornuelle, B.D.; Miller, A.J.; Powell, B.; Chua, B.S.; Bennett, A.F. Weak and strong constraint data assimilation in the inverse Regional Ocean Modeling System (ROMS): Development and application for a baroclinic coastal upwelling system. Ocean Model. 2007, 16, 160-187. [CrossRef]

204. Jiang, D.J.; Wang, X.L. Variation of Runoff Volume in the Dagu River Basin in the Jiaodong Peninsula. Arid Zone Res. 2013, 30, 965-972. (In Chinese)

205. Shi, J.; Dong, X.L.; Zhao, T.J.; Du, J.Y.; Jiang, L.M.; Du, Y.; Liu, H.; Wang, Z.Z.; Ji, D.B.; Xiong, C. WCOM: The science scenario and objectives of a global water cycle observation mission. In Proceedings of the 2014 IEEE Geoscience and Remote Sensing Symposium, Quebec, QC, Canada, 13-18 July 2014; pp. 3646-3649.

206. Lee, C.M.; Cable, M.L.; Hook, S.J.; Green, R.O.; Ustin, S.L.; Mandl, D.J.; Middleton, E.M. An introduction to the NASA Hyperspectral InfraRed Imager (HyspIRI) mission and preparatory activities. Remote Sens. Environ. 2015, 167, 6-19. [CrossRef]

(C) 2019 by the authors. Licensee MDPI, Basel, Switzerland. This article is an open access article distributed under the terms and conditions of the Creative Commons Attribution (CC BY) license (http://creativecommons.org/licenses/by/4.0/). 